\title{
Focillón y Strzygowski o la lejana raíz del arte occidental
}

\author{
Julio Arrechea Miguel *
}

En carta a Clara Rilke de 1907 el poeta expresaba la tensión que le producia el ambiente moderno y superficial del Tívoli parisino, ambiente irreal, como la propia ciudad, pues en él se pierde «...el pie, el aire, el cielo, toda realidad». También a los ojos de Benjamin París aparecía como la un poco molesta e ilusoria "ciudad de los espejos" ', especie de fantasmagoría superadora de una realidad ancestral que el propio Benjamin se encargará de teorizar. Ni uno ni otro podían ser ajenos a aquella generalizada y polémica búsqueda de las raíces culturales europeas que en Alemania sintetizó estéticamente, en su forma más radical, en el concepto de "Heimatkunst» (arte de la patria) difundido desde 1897 por Ernst Rudolff, movimiento conservador, nacionalista, anticosmopolita, y de posterior tendencia racista de gran peso en la cultura alemana ${ }^{2}$. Bien es cierto que estas corrientes de pensamiento no eran específicamente alemanas y que buena parte de ellas atravesaron Europa afectando los dominios de la política, la cultura, el arte, y la historiografía; pues en aquellos años Europa descubría, súbitamente y con pesar, el espesor, lejanía y sentir "originario" de la que la dotaban disciplinas como la moderna arqueología - la lingüística. La propia definición de un nuevo y funciamental concepto cuyo nacimiento hay que situar en este período, la idea de "Occidente", participa de esta trama de polémicas ideológicas en donde hasta la ciencia tomó partido ${ }^{3}$.

* Universidad de Valladolid.

Benjamin, W., Paris, capitale du xix siecle. Paris, CERF, 1989, págs. 552-558. Rilke, R. M., Briefe über Cèzanne, 1952 (ed. española. Barcelona, Ed. Paioos, 1986, pág. 46).

2 PETSCH. Joachim, "il Deutscher Werkbund dal 1907 al 1933 e i movimenti di riforma della vita e della cultura", en Werkbund. Germania, Austria, Svizzera. Venezia, Edizioni "LA BIENNALE" 1977, págs. $85-93$

3 Sobre el movimiento conservador, nacionalista y racista francés ver: DE Roux, M., Charles Maurras et le nationalisme de l'Action Francaise. Paris, Bernard Grasset Editeur, 1927. 
Acostumbrados a una interpretación de las obras de arte de la que parece haberse eliminado los valores ideológicos, resulta difícil reconstruir el significado moral, originario y fundacional que para los intelectuales del período tuvo la Edad Media. Olvidada por casi todos los historiadores del arte en la actualidad, mirada con reservas, puesto que de ella no parece surgir con claridad el universo humanista que ilumina al Renacimiento, el arte y la arquitectura de la Edad Media fue, sin embargo, y durante más de un siglo, el lugar en donde se amalgamaron las más extrañas y avanzadas hipótesis estéticas y constructivas. Y fue en este ambiente apasionado por el valor "profundo" de la cultura medieval en donde las agrias discusiones nacionalistas tomaron valor y en donde se opusieron defensores de un "origen" de Europa germanista frente a una idea de latinidad, específicamente romana, como fundamento y causa perpetua de los diversos renacimientos occidentales ${ }^{4}$.

Buena parte de todos estos avatares, y desde luego su estado final, se pueden reconstruir a través de una importante polémica suscitada en una fecha tan tensa como lo fue 1935 y publicada en el Boletín del Instituto Internacional de Cooperación Intelectual de la antigua Société des $\mathrm{Na}$ tions. El paradigmático título de los textos (Civilisations. Orient-Occident. Genie du Nord-Latinité. Lettres de H. Focillon, G. Murray, J. Strzygowski, R. Tagore) no deja lugar a dudas sobre qué temas estaban en discusión. Entre Strzygowski y Focillon se repitió la secular polémica sobre el "origen" (nórdico o latino) de Occidente, lo que en aquel momento pasaba por la dilucidación de los valores culturales y artísticos de la Edad Media y su deuda bien con las razas nórdicas pretendidamente portadoras de una nueva estética (Strzygowski), o con la tradición clásico-latina (FociIlon).

En opinión de Joseph Strzygowski, sobre el que volveremos más tarde, el imperialismo histórico de los pueblos mediterráneos impuso sobre los pueblos de septentrión un dominio político que también se convirtió en estético. Sin embargo estos pueblos del norte, con su diferente organización política, sensibilidad formal y técnicas, fueron, desde míticos "orígenes", los oscuros y lejanos impulsores de corrientes estéticas como el arte griego, el gótico, el barroco, el romanticismo o el arte expresionista; en definitiva, el dominio del espírutu sobre la técnica y el carácter sagrado del Todo (ambiente físico del hombre nórdico) constituyen los rasgos

4 Buen resumen de las diversas tesis lo realizó Pierre Francastel en L'histoire de l'art ins. trument de la propagande germanique. Paris, Editions politiques, économiques et sociales, Librairie de Médicis, 1945. 
esenciales de la difusa estética neoromántica que Strazygowski identifica con la vida síquica de los pueblos del norte ${ }^{5}$.

\section{FOCILLON Y EL CLASICISMO FRANCÉS}

La elegante defensa de la "latinidad» que Focillon utilizó como respuesta al texto de Strzygowski, está unida a una tradición interpretativa basada en el sentido del "orden" que durante el siglo XIX se había extendido a la valoración de muy diversos aspectos y momentos del arte incluyendo la Edad Media occidental. En realidad buena parte de la ambiciosa obra de Focillon intenta demostrar hasta que punto la base artística subyacente de la cultura europea (el «humanismo») fue capaz de definir y sintetizar, entre los siglos $\mathrm{xI}$ y $\mathrm{x} \mid \mathrm{x}$, una cultura y un arte ecléctico propiamente europeo. Títulos paradigmáticos como el Art d'Occident (1938), L'an mil (1952) o su conocida Vie des formes (1934) son deudores a ideas clave en su interpretación de la historia. Es así como los conceptos de "forma" y "estilo" constituyen la pantalla sobre la que Focillon recorta la universal evolución de las formas, desde el arte oriental al Renacimiento clásico.

El clasicismo de Focillon, sin embargo, aun manteniendo relación con la tradición francesa objetivista está profundamente modificado por nuevos criterios historiográficos y estéticos. Por ello, adquiere especial relevancia su teoría de los desarrollos desiguales de las formas y el interés por aquellos momentos de tensión de la historia en donde arcaísmos y precocidades sintetizan; y de aquí deriva, igualmente, la centralidad que para Focillon posee la idea de «formatividad" creativa o de "apropiación», ya que representa el momento en que la vida interior del artista toma conciencia de las formas que en su interior deambulan, erráticas, como metáforas de un grabado de Piranesi ${ }^{6}$.

No podemos olvidarnos que el conjunto de la obra del historiador francés se desarrolla en un momento especialmente polémico de la vida cul-

Strzygoskı, Jospeh, "A Herıri Focilion" en Civilisations. Orient-Occident. Genie du Nord-Latinité. Lettres de H. Focillon, G. Murray, J. Strzygowski, R. Tagore. Institut International de Coopération intellectualle. Société des Nations, 1935, págs. 75-127, págs. 97, 104.

$6 \quad$ La relación entre conciencia creativa y los complejos microcosmos de los grabados de Piranesi fue conscientemente buscada por el historiador francés: Vie des formes (Ed. española. Madrid, ed. Xarait, 1983, pág. 52). A este respecto se debe recordar que la primera gran síntesis sobre los grabados de Piranesi constituyó la tesis doctoral del propio Focillon leida en 1911 y publicada en Paris por Laurens en 1918. Sobre la evolución teórica de la obra de Focillon ver la obra colectiva: Henry Focillon. París, Centre Georges Pompidou, 1986; sobre todo el texto de Jean Bony "Henry Focillon ou la généalogie de l'unique», págs. 21-42. 
tural francesa en buena medida dominada por el nacionalismo, conservadurismo y antigermanismo de I'Action Francaise del que Charles Maurras se convirtió en su principal representante. Desde el punto de vista estético el movimiento francés derivó, y terminó imponiendo, una crítica al germanismo como cultura bárbara que directamente Maurras situaba "fuera de la humanidad" ${ }^{7}$. Esta misma obsesión antigermana está presente en los escritos de diversos teóricos e historiadores del arte francés de principios del siglo como Louis Dimier o Emile Mâle. Para el primero de ellos, que publicó en 1902 una curiosa Réponse à une Enquête sur le passè et l'avenir de l'Influence allemande chez les Francais, la cultura alemana ha terminado por hacer arraigar entre los franceses un cierto anarquismo romántico junto a una idea de superioridad germana; desgraciadamente esta cultura ha ido acompañada de fuertes dosis de absolutismo filosófico, nacionalismo y pangermanismo. Frente a ello el historiador nos propone una reacción europea que recupere la vieja herencia clásico-latina, recusando, en bloque, las ideas de Weimar, la estética de Lessing y el patetismo de Schiller ${ }^{8}$.

Desde el punto de vista estético el neo-latinismo francés estuvo acompañado de una fuerte revitalización del concepto clásico de belleza del que la idea de "armonía" es su eje fundamental. Si la sensibilidad romántica es capaz de generar violentas y grandes sensaciones en ningún momento es capaz de disponer o componer un equilibrado sistema de relaciones: una armonía ${ }^{9}$. En la exaltación de estos aspectos hay que valorar el bello y raro texto de Henri Provensal Vers l'harmonie intégrale. $L$ 'art de demain publicado en 1904 en el que el autor exigía la necesidad de un clasicismo sometido a las leyes de unidad, número y armonía pero que fuese capaz de generar un nuevo simbolismo adecuado al espíritualismo de la época. Desde luego en el texto de Provensal, que otorga una cierta preferencia a la arquitectura, se detectan signos de una profunda lectura y asimilación del romanticismo francés y del simbolismo. El poder de la arquitectura consiste en que no sólo es capaz de hacer posible la sintesis universal de las distintas artes o de las diversas armonías "fragmentarias", sino que constituye la "expresión cúbica armoniosa del pen-

DE Roux, M., Op. cit., págs. 225.

8 Dimier, L., Réponse à une Enquête sur le passè et l'avenir de l'Influence Allamande chez les Francais. París, Mercure de France, 1902, págs. 6-7. "No, la Europa literaria e intelectual (...) no ha ganado en nada con este cambio, y no ha debido felicitarse al pasar de las manos de la Francia latina a las de la Alemania romántica". 61

Raymond. Marcel, De Baudelaire au Surréalisme. Paris, Librairie José Corti, 1952, págs. 
samiento" y uno de "los más bellos dramas plásticas del mundo" "; en ultima instancia una mistoriosa Idea Universal de Armonia, extensible desde las cristalizaciones del reino mineral, subyace al texto de Provensal; en la sintesis exigida entre la sencillez del nuevo arte, sus formas elementales y su generalización simbólica existe la posibilidad de realizar “... el signo abstracto, revelador del misterio por el cual el hombre entrará en contacto con el infinito" ".

\section{ROMÁNICO Y GÓTICO EN LA ARQUEOLÓGICA MEDIEVAL FRANCESA}

Pero Focillon no sólo se movía en un ambiente cultural proclibe al antigermanismo y al clasicismo. Desde su cátedra de arqueología medieval en la Sorbona, en la que sucedió en 1924 a Emile Mâle, Focillon se convirtió en el heredero directo de una larga escuela de arqueólogos e historiadores que a lo largo del siglo $\mathrm{x} x \mathrm{x}$ sentaron las bases interpretativas de las arquitecturas románica y gótica. Casi todos ellos, con escasas excepciones, centraron sus investigaciones en la posibilidad de definir en forma sistemática y clara los elementos, relaciones, influencias y diferencias entre los dos grandes estilos arquitectónicos medievales. Sus apasionantes discusiones teóricas abundantes en contenidos técnicos y estéticos todavía están por describir y, en mi opinión, podrán revelar importantes datos sobre la evolución del neomedievalismo y sobre su influencia en la propia teoría y práctica de la restauración ${ }^{12}$.

Con el gran arqueólogo normando Arcisse de Caumont se inicia en Francia una visión analítica hacia el pasado. La importancia de su figura aún no ha sido suficientemente iluminada en buena medida por haber permanecido a la sombra de las grandes figuras del romanticismo literario francés. En 1823 Caumont funda, a ejemplo de las organizaciones inglesas, la conocida Sociedad de Antiquaros de Normandía base de la futura y activa Sociedad Francesa de Arqueología. El mismo año aparece el primer número del importante Bulletin monumental que será el receptáculo, a lo largo de todo el siglo, de las más vivas discusiones arqueológicas. En diversas publicaciones Caumont se encargó de ofrecer una primera

Provensal. Henri. Vers I'harmonie intégrale. L'art de demain. Paris, Perrin et Cie., Librai. res-Editeurs, 1904, págs. 158-159.

Provensal. Henri, Op. cit., págs. 318-319.

Importante documentación en torno al medievalismo francés y a las importantes Sociedades Arqueológicas se encuentra en los volúmenes del XCVII Congrès Archélogique de france. Paris, A. Picard. 1935, 2 vols. que fueron publicados en conmemoración del Centenario del Servicio de Monumentos Históricos y de la Sociedad Francesa de Arqueología 
sistematización de la arquitectura medieval; así sucede con su Essai sur l'architecture religieuse du moyen âge (1824) o con su conocido Abécédaire ou Rudiment d'archeologie (1850).

Al describir al románico como una arquitectura sin futuro histórico, como una mera "degenerescencia de la arquitectura romana" ${ }^{3}$, Caumont afirmaba el misterioso origen de la arquitectura gótica cuyos edificios no eran inscribibles en una línea evolutiva que tuviese su génesis en el primer estilo románico. En efecto, frente a la aparente estabilidad y tradición tipológica del románico se abría en el siglo xII una arquitectura completamente distinta, cuya espectacularidad y belleza rompian estéticamente con la pesada y robusta arquitectura anterior. La arquitectura gótica, por tanto, resultó para estos primeros historiadores un misterio abierto cuyas causas buscaron afanosamente no llegando a aceptar, en la mayoría de los casos, la tradición romántica que atribuía a los pueblos del norte una arquitectura y arte tan sofisticados. En realidad Caumont Ilega a proponer un cambio de denominación de la vieja arquitectura gótica puesto que, en efecto, los bárbaros solamente fueron capaces de imitar las construcciones romanas y cuando el denominado "estilo gótico" se encontraba en su apogeo aquellas tribus originarias habian desaparecido de Europa ${ }^{14}$.

No es extraño, por tanto, que tras la primeriza sistematización de Caumont la arqueología medieval centrase sus preguntas en aquellos aspectos más llamativos de la arquitectura de la Edad Media. Y el más fascinante de todos ellos era, sin duda, el del origen de la ogiva. Ya el Congreso Arqueológico Nacional celebrado en Poitiers en 1834, y cuyas discusiones fueron recogidas por el Bulletin monumental, fue dedicado monográficamente al estudio de este problema prefigurándose en él algunas de las discusiones que dominaron la interpretación del gótico durante cerca de cien años. Es aquí cuando aparece una interpretación fundamentalmente técnico-formal de la ogiva, entendida de diversas formas: bien como refuerzo cuya finalidad es concentrar los empujes, como una respuesta natural a ia evolución de la bóveda de aristas 0 , algo más absurdamente, la comprensión de la ogiva como respuesta típicamente septentrional a la necesaria elevación de las cubiertas ${ }^{15}$. Atrevidas pero

13 De Caumont, Arcisse, "Histoire sommaire de l'architecture Religieuse, Militaire et Civile", en Bulletin Monumental. Paris-Caen 1836, 427 págs. Extracto del Cours d'antiquités monumentales, 1830, págs. 25-26.

14 De Caumont, Arcisse, Op. cit., pág. 27

15 "Nouvelles Archéologiques", en Bulletin monumental. París, Caen, 1834, N. 2, págs. 80. 84 , y N. 3 , págs. $85-91$. 
muy en línea con el potente orientalismo romántico se manifiestan las tesis de teóricos que, como Lenormant, Schweighauser o el propio Caumont, gustaban atribuir a este procedimiento formal un origen geográfico remoto como es el caso de la arquitectura árabe y árabe-española.

\section{LA CONTINUIDAD "CLÁSICA»DE LA ARQUITECTURA MEDIEVAL: QUICHERAT Y EL ROMANISMO}

El avasallador dominio del pensamiento constructivo, principal apoyatura del clasicismo arquitectónico decimonónico, ayudó a que la escuela arqueológica francesa fuese depurando estas hipótesis de sus aspectos más fantásticos e incoherentse. Sin recurrir a la majestuosa interpretación "violletiana" de la arquitectura medieval, debe recordarse que personajes como Vitet fueron conscientes de la necesidad de reelaborar desde la íntima estructura interior la historia de la arquitectura medieval. Y esta Interpretación de la arquitectura no podia aceptar fácilmente el hiato entre los dos grandes estilos medievales que indicaba Caumont. Un conocido texto del propio Vitet sobre la catedral de Noyon ${ }^{16}$ de 1844 , fue la firme base para los posteriores estudiosos que centraron su investigación en el tema clave de la "transición" estilística entre románico y gótico. Monumentos híbridos como los grandes edificios religiosos de Noyon, Soissons o Laon despertaron pronto el interés de los arqueólogos porque en ellos residía el misterio de una fascinante evolución. Al amparo del firme método establecido por las ciencias naturales o la lingüística ${ }^{17}$, los historiadores procuraron definir la evolución de una lógica constructiva que se dirigía, desde el siglo $x$, a la constitución precisa del sistema gótico canónico como era observable en Reims o Amiens.

La década de los cuarenta significó en Francia la aparición de una poderosa escuela medievalista con ramificaciones en la arquitectura, historia, literatura o arqueología ${ }^{18}$. Al margen de la fundamental labor didáctica y proyectual de Viollet-le-Duc no debe olvidarse la función de-

is Vitet, Ludovic, “Notre-Dame de Noyon" (1844) en Etudes sur l'histoire de l'art. Paris, Michel Lévy frères, éditeurs, 1875, 4 vols., vol. 2, págs. 1-232.

Sobre la importancia del denominado "metodo comparado" entre los arquitectos, teóricos o historiadores del siglo XIx ver Julio Arrechea. "Composición e historia en el pensamiento arquitectónico del siglo xix», en Fragmentos. Madrid 1989, N. ${ }^{\circ}$ 15-16, págs. 84-97.

18 Debe subrayarse la aparición de arquitectos conocedores de los sistemas medievales de construcción que como Lassus y Viollet-le-Duc pudieron entrentarse a la restauración de obras emblemáticas como la Santa Capilla de París o Vezelay. En cuanto a la prensa arqueológica debemos recordar la aparición de los militantes Annales archéologiques de Didron, la Revue archéologique o la Revue de l'art chrétien. 
sarrollada desde la cátedra de arqueología de l'Ecole de chartes por el gran maestro de los historiadores y medievalistas franceses: Jules Quicherat. A su herencia, recogida posteriormente y en forma fragmentaria por su discípulo Robert de Lasteyrie en unos interesantísimos Melanges d'archeologie et d'histoire (1885-1886), se debe la formación de toda una escuela de magníficos arqueólogos e historiadores como el propio Lasteyrie, Saint-Paul, Lefèvre-Pontalis, Enlart, Aubert o Brutails.

Ejemplarmente didáctico y metodológicamente exacto Quicherat centró alguno de sus más relevantes artículos en la definición del elemento "esencial" que diese la pauta de la evolución lógica entre románico y gótico y que uniese estos dos estilos a una tradición occidental específicamente romana. Todavía hoy día sigue pensándose que este elemento permanente, aunque en constante cambio en la arquitectura medieval, es la bóveda. Su aparición implicó, según Quicherat, un complejo sistema de deformaciones y un dominio de la masa en el tradicional tipo basilical. Los intentos de solucionar tales inconvenientes condujeron a la aparición del arco fajón y posteriormente del formero a la vez que se aligeraba el peso de la bóveda con la aparición de las ogivas ${ }^{19}$.

Las conquistas de Quicherat, dominadas por un mecanicismo constructivo y deductivista, fueron fundamentales para iniciar la comprensión de la arquitectura medieval y no menos importantes fueron las consecuencias posteriores de tal tipo de interpretación. Tanto Quicherat como posteriormente Saint-Paul o Lasteyrie definen el elemento esencial e interior de aquella arquitectura en términos técnicos; la bóveda o, más complejamente, el tramo de nave o la estructura de "baldaquino" que determinan fajones y formeros constituye el gran avance que, frente a la arquitectura romana, posibilita «romper la contigüidad de las piezas» ${ }^{20}$ (fig.

"QuICHEAAT, Jules, "De l'architecture romane"(1851), en Melanges d'archeologie et d'histoire. Paris, A. Picard, 1885-1886. 2 vols., Vol. II, págs. 86-152.

(1) Quicherat, Jules, “De l'architecture romane» (1851), Op. cit, pág. 95. Las mismas tesis fueron defendidas años más tarde por A Saint-Paul en un artículo específicamente titulado "La Transition" publicado en Revue de l'Art Chretien. Paris 1894 y 1895, págs. $470-482$ (1894) y 1 20,97-107 (1895), asi como en su critico texto hacia la obra de Viollet-le-Duc y titulado Viollet+ le-Duc ses travaux d'art et son système archéologique. París, L'année Archéologique, 1881 (segunda edic.).

Consecuencia de esta interpretación técnica es la descripción gráfica que tiende a darse del edificio medieval en donde predomina la visión de la sección del edificio y su alzado interior. El propio Quicherat en el artículo anteriormente citado, Viollet-le-Duc en el Dictionnaire raisonné de l'architecture trancaise du xI au xviè siécles. (París, B. Bance, 1854-1868), LASTEYRIE, R. de, en L'Architecture religieuse en France a l'époque romane. (París, Auguste Picard editeur, 1929, 2 vols., 1 edición de 1911) o Brutails, J., en su difundido Précis d'archeologie du moyen age (Paris, Henri Didier, 1936) suministran abundantes tipos de esquemas clasificatorios. 


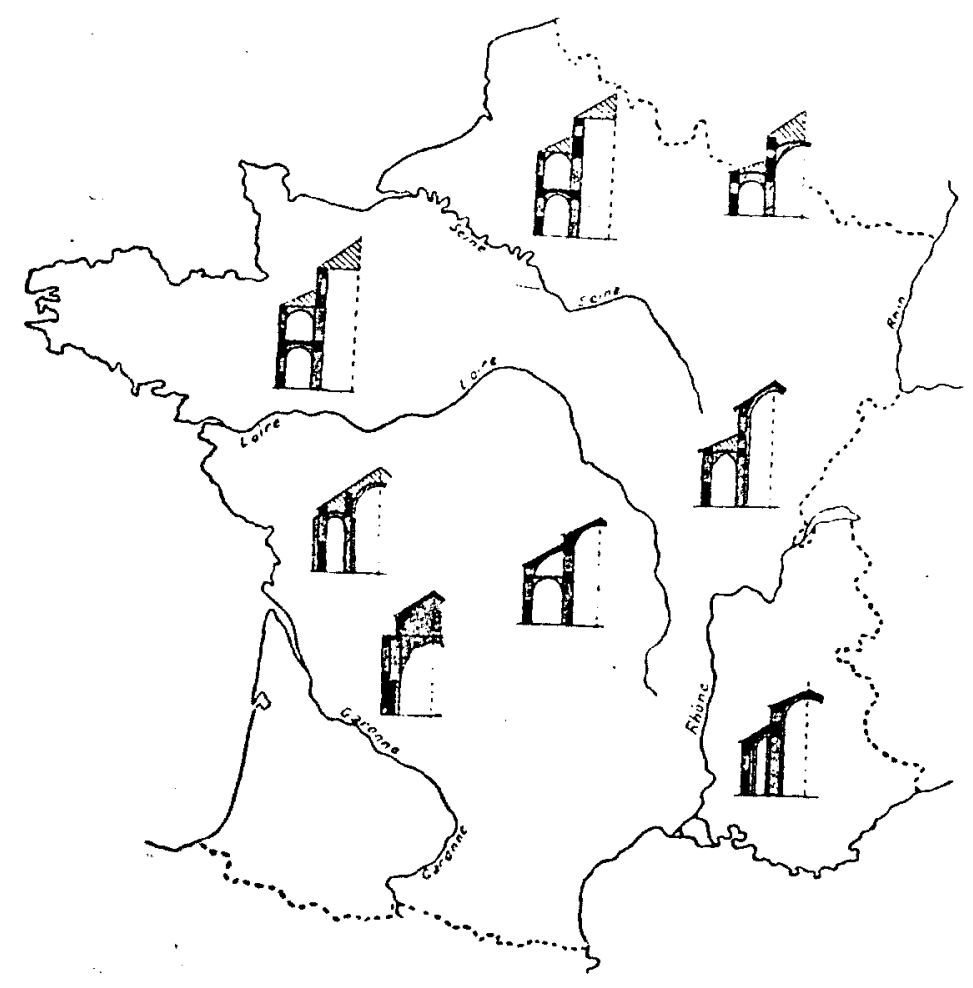

Fig. 1. Brutalls. Geografía del románico. 1900

1). Es la aparición de este tipo de estructuras genéricas el que garantiza constructivamente la continuidad y organicidad del arte medieval eliminando la cesura que los primeros arqueólogos habían establecido.

A pesar de su atractiva perfección este tipo de interpretaciones son poseedoras de serias limitaciones. Al menos dos de ellas deben señalarse; en primer lugar se asiste a lo largo del siglo a una pérdida de identidad del románico cuya historia queda reducida a la línea evolutiva que permite la invención de la bóveda de crucería y, con ello, de paso a la arquitectura gótica. En segundo, esta misma limitación interpretativa basada en los procedimientos técnicos dio lugar a un monumental «abuso de los sistemas científicos», como lo denominó Brutails, llegándose a proponer hi- 
pótesis francamente fantásticas a la filiación de los elementos que componen la arquitectura gótica ${ }^{21}$.

\section{STRZYGOWSKI Y LAS TEORIAS DIFUSIONISTAS}

Por un breve espacio de tiempo los mecanismos interpretativos generados por la escuela francesa parecieron iluminar en forma definitiva el complejo misterio de la arquitectura medieval estableciendo una hilazón lógica entre ésta y Roma. Gracias a ello la catedral de Reims devino el prismático y perfecto modelo del mayor momento de esplendor de determinado procedimiento técnico. De hecho, el clasicismo de Focillon está intimamente unido a la claridad de procedimientos que se revela en esta interpretación del gótico. Sin embargo en su obra aparecen ciertos puntos oscuros que contradicen el modelo; es el caso del interés que revela hacia la arquitectura prerománica u oriental. Problemas heredados, pues ya a mediados del siglo xIX la mirada transparente y cristalina que Quicherat había impuesto hacia la Edad Media, se volvía opaca.

En línea paralela a lo sucedido en el ámbito de disciplinas como 1 la antropología, en el terreno de la historia de la arquitectura pronto entró en crisis el optimismo evolucionista que dominaba la arqueología medieval. Las causas y efectos de estos desajustes son sumamente complejas y buena medida unidas al propio desarrollo del positivismo. En cualquier caso, no podemos olvidar datos reveladores provenientes tanto de la naciente arqueología prehistórica como de la geología, disciplinas que, en sus inicios, estuvieron íntimamente unidas. El eje sobre el que giraba la cultura científica europea a mediados de siglo era el del descubrimiento de la inmensa profundidad temporal del pasado de la Tierra y del Họmbre.

Sabemos que las teorías geológicas denominadas "uniformitaristas", y reflejadas en la obra de Charles Lyell, (Principles of Geology. Londres, 1831-1833) revolucionaron la idea que sobre la edad de la Tierra y sobre el sentido del tiempo poseía la cultura dieciochesca ${ }^{22}$.

21 Es el caso de las hipótesis sobre el origen del arbotante que se hace descender de las bóvedas de cuarto de canón corridas situadas sobre las naves laterales de las iglesias románicas del Midi francés. Una severa crítica al tema se encuentra en el romanista BrUTAILS, J. A., L'Archéologie du Moyen Agen et ses méthodes. Paris, Alphonse Picard et fils, éditeurs, 1900. págs. 143 y ss.

22 El "uniformitarismo" es básicamente una teoría interpretativa del tiempo. Su idea central es la de que el "tiempo lento", es decir la transformación geológica tal y como la percibimos en la actualidad es extrapolable a todos los periodos de la historia de la Tierra. Con ello se 
La profundidad temporal ofrecida por los estudios geológicos fue acompañada por la maduración de la antropología y arqueología prehistórica que completaron su espacio científico. Ambas disciplinas, al crear los mecanismos de conocimiento del hombre y sus obras, incluyendo la aparición de las primeras teorias raciales y etno-lingüisticas, llegaron a la conclusión de que los seres humanos, a pesar de la remota antigüedad de sus culturas, poseían una naturaleza básicamente estática por lo que resultaba improbable que determinadas invenciones se produjesen más de una vez en la historia humana. En consecuencia, la aparición de determinada técnica, objeto o tipo ornamental sólo era explicable en términos migracionistas o difusionistas. Los alemanes Friedrich Ratzel y Franz Boas junto al escandinavo Oscar Montelius fueron los más conocidos representantes de esta tendencia. La obra más polémica de este último Der Orient und Europa (1899) insistía en situar los orígenes de la cultura europea en el gran foco del Próximo Oriente ${ }^{23}$. Similares tesis migracionistas fueron sostenidas desde la escuela vienesa de antropología por F. Graebner y W. Schmidt, que afirmaban que en las planicies de Asia central se habia desarrollado una serie única de culturas primigenias desde donde se habian difundido a diversas partes del mundo ${ }^{24}$.

Con toda seguridad Joseph Strzygowski, de origen checo y también profesor por las mismas fechas en Viena, estuvo en contacto con este grupo de antropólogos pues sus tesis historiográficas son incomprensibles sin la existencia de un sistema masivo de pretéritas migraciones orientales

oponia radicalmente a las teorías "catastrofistas", en buena medida apoyadas por los Textos Sagrados, que explicaban la conformación de la Tierra, sus irregularidades, cordilleras y gargantas por la existencia en el pasado de fuerzas inmensamente poderosas y sin comparación en el mundo actual.

La historia de alguna de las más importantes polémicas decimonónicas en el terreno geológico ha sido elaborada por HaLLAM, Anthony, Great Geological Controversies. Oxford, University Press, 1983 (existe ed., castellana en editorial Labor. 1985), págs. 42-59.

23 Sobre la historia de la arqueología y la antropología con paiciales capítulos dedicados al "difusionismo" son interesantes a un nivel muy general la obra de Trigger, Bruce G., A History of Archaecological Thought. Cambridge, University Press, (trad. española de Editorial Critica, 1992) y la de HaRRIS, Marvin, 1989. The rise of antropological theory. A history of theories of culture. 1968 (trad. española en Siglo xxi. de España Editores, 1987). Un clásico de la historia de la arqueología sigue siendo la obra de DANIEL, Glyn, A Hundred and Fifty Years of Archaeology. Londres, Duckworth, 1950. (trd. española en México, FCE, 1987). Una reflexión actualizada sobre los métodos y la teoría arqueológica se encuentra en la obra de SaLmon, Merrilee $H$., Philosophy and Archaeology. New York, Academic Press, 1982.

${ }_{24}$ Triggert, B. C., Op. cit, págs. 147. Las tesis migracionistas orientales estuvieron muy presentes en el pensamiento arqueológico desde la década de los setenta. Me remito a las discusiones en torno al tema publicadas por Vilanova y PIERA J. y Tubino, F. M., en su obra Viaje científico á Dinamarca y Suecia con motivo del Congreso Internacional Prehistórico celebrado en Copenhague en 1869. Madrid. Imprenta de A. Gómez Fuentenebro, 1871, págs. 39 y ss. 
hacia Europa. Iniciado como historiador en el apasionante mundo del arte bizantino, nuestro radical profesor puso pronto en duda, frente a la escuela francesa, la aportación original y fundacional de la cultura romana que, en su opinión, lo único que hizo fue recibir y sintetizar, desde el Próximo Oriente, un inmenso repertorio de formas ya elaboradas. Su primera y significativa gran obra Orient oder Rom (1901) intentaba probar la existencia de un Oriente mediterráneo dominado por una cultura helenistica cristiana que poca deuda tiene con Roma. Con el tiempo el helenismo irá dejando su lugar a culturas más lejanas, Irán o Mesopotamia, que se convertirán en el verdadero hogar artístico de la humanidad. En cualquier caso esa orilla mediterránea oriental, sobre todo Siria, será siempre la catapulta desde la que las formas se lancen a la conquista de occidente. No es de extrañar, por tanto, que Strygowski se enfrentase con Wickhoff y Riegl en torno a la noción de uarte imperial» difundida por estos últimos para justificar la existencia de un arte específicamente romano. En el clima neoromántico de fin de siglo el aura de sus tesis dio a Strzygowski tal fama como historiador del arte, que una importante revista francesa dirigida por el propio Focillon, L'Amour de l'Art, le dedicó en 1932 un número monográfico en el que llegaba a comparar su labor sintética con la del propio Wölfflin ${ }^{25}$.

Francastel ha señalado al respecto de la obra de Strzygowski la influencia que sobre él tuvieron Courajod y Ruskin ${ }^{26}$. En absoluto es extraña esta mezcla de positivismo arqueológico e idealismo romántico que por ambas vías finaliza en la compleja interpretación del arte y la arquitectura que encarna el romanticismo y especificamente Victor Hugo. De hecho, muy tempranamente el poeta ya había cantado las excelencias de la nueva mirada hacia al Oriente en una bellísima introducción a Les Orientales (1929) que finalizaba con una reflexión sobre Asia como un inmenso abismo cultural en el que se han volcado nuevas generaciones de estudiosos y que, con el tiempo, llegará a sustituir a los estudios clásicos ${ }^{27}$. El orientalismo literario francés a través de Volney, Nerval, Flaubert, Chateaubriand o Gobineau, en efecto, fue el fundamento de toda posterior tendencia arqueológica y filológica que pretendía abarcar desde la cultura mesopotámica e iraní hasta la bizantina ${ }^{28}$. La interpretación de Strzy-

25 Malkiel JiRmounsky. Miron, "Quelques aspects de l'oeuvre de Strzygowski» en L'Amour de l'Art. París, Mars 1932, N. 3, págs. 77-82

26 Francastel. Pierre, L'histoire de l'art instrument de la propagande germanique. Paris, Editions politiques, économiques et sociales, Librairie de médicis, 1945, págs. 234-236.

${ }^{27}$ Hugo, Víctor, Odes et ballades. Les Orientales. París, Imprimerie National, Librairie Ollendorf, 1912 (1 ed. 1829), págs. 618

${ }^{28}$ El orientalismo como «ideologia de occidente" ha sido recientemente estudiado por Edward W. Said en Orientalismo. Madrid, Ediciones Libertarias, 1990. Los avatares de la arqueología oriental han sido descritos por DaniEL G., Op. cit., págs. 69 y ss 


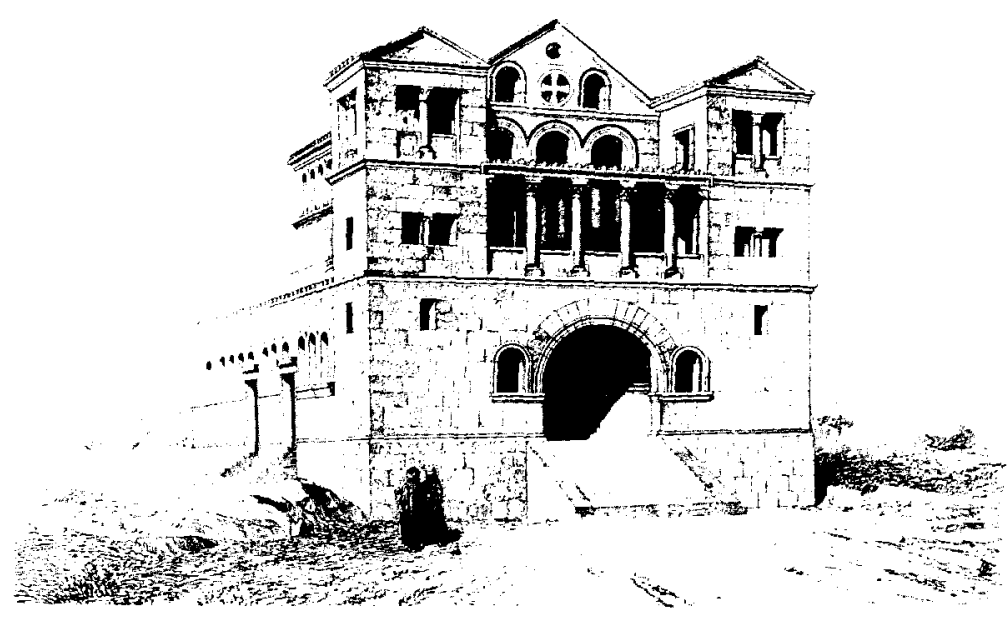

Fig. 2. Vogue Iglesia de Tourmanin (restitución), en Syrie Centrale.

(1866-1875)

gowski del nacimiento de la arquitectura medieval y de la paralela constitución de Occidente que subyace en todas sus obras, es también deudora a la escuela arqueológica bizantinista francesa representada por Verneilh, Vitet, Diehl, Choisy, Dieulafoy o Vogüe.

\section{RACIONALISMO Y DIFUSIONISMO DE LA ARQUITECTURA SIRIA}

Fue el marqués de Vogüe, en efecto, el máximo responsable del brusco movimiento producido en el medievalismo francés cuando publicó entre 1865 y 1877 su conocidísima Syrie centrale. Architecture civile et religieuse du ler au VIIe siècle. Si las tesis migracionistas o difusionistas empezaban a afirmarse en el ámbito del arte primitivo, fue suficiente la divulgación de las láminas de aquella magnífica publicación (fig. 2) para que surgiese ante los ojos de los europeos la idea de una arquitectura en la que parecía encontrarse el germen original del arte del occidente medieval.

Que la imaginación de arquitectos y críticos, tan predispuestos a las grandes sintesis, se encendiese a la vista de aquellas láminas incluso hoy día parece lógico. $Y$ no es de extrañar que una sensibilidad romántica como la de Viollet-le-Duc se extasiase ante aquellos edificios de los siglos 


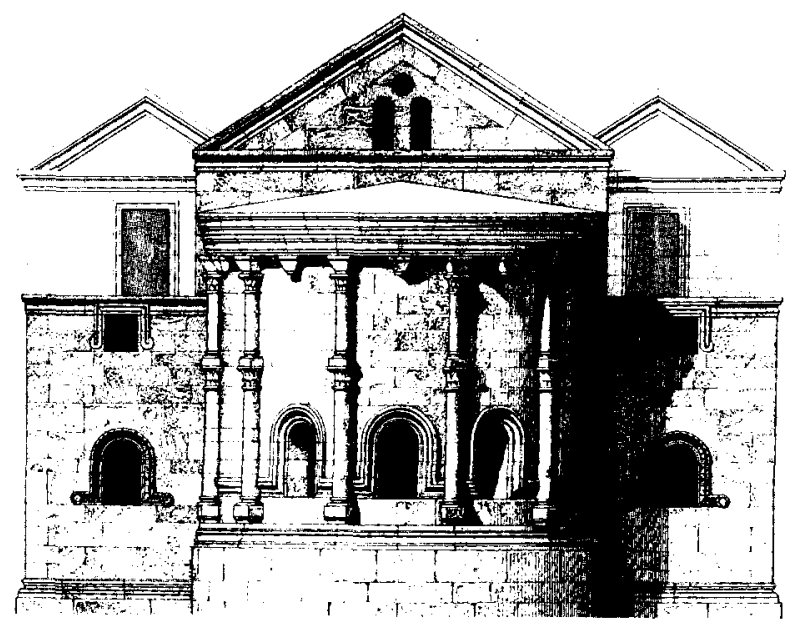

Fig. 3. Vogue. Ábside restituido de Qalb-Louzeh.
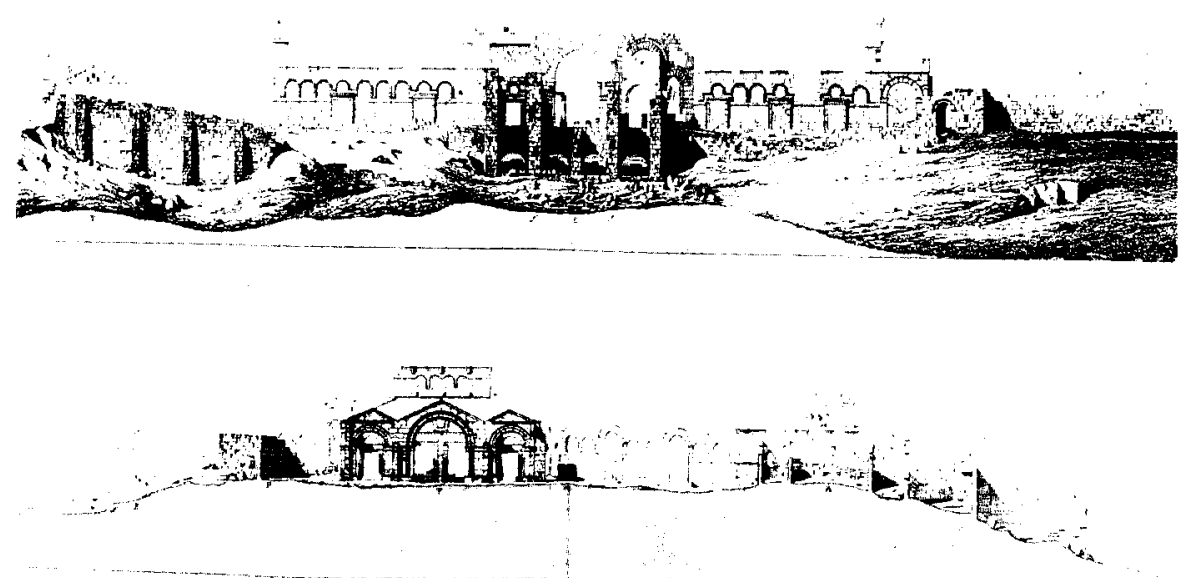

Fig. 4. VOGUE. Monasterio de Kalat Sema'n.

$\checkmark$ y VI y buscase en ellos la solución "migracionista" - a través de las Cruzadas de fines del siglo $x$ - al enigma del arte occidental. En opinión de Viollet la arquitectura siria anunciaba una perfecta unión entre las plantas basilicales con sistemas romanos de arcadas y la clara y lógica estructura de la sillería griega, sintesis que debió influir poderosamente en 
los arquitectos occidentales. Junto a las bellas disposiciones de iglesias - manasterios como Tourmanin, Qalb-Louzeh o Kalat Sema'n (figs. 3 y 4), la zona de Haouruan ofrecía los mejores ejemplos de una arquitectura de arcadas sobre la que apoya un sistema de finas losas horizontales, como en el caso de la iglesia de Chagga y del que los arquitectos occidentales hacen derivar, nos dice, nada menos que el sistema tradicional románico de arcos fajones y pilar compuesto ${ }^{29}$. En resumen, según Viollet Siria debió representar para los constructores de la Edad Media la idea de «... una arquitectura nueva, clara en sus expresiones como una lección bien dada, fértil en deducciones, fácil de comprender y pudiendo ser apropiada a todas las necesidades" ${ }^{30}$ (fig. 5).

Paradójicamente, cuando por fin fue publicada en 1877 el texto introductorio de Vogüe, su autor parecía algo reticente a las tesis del conocido arquitecto. Es cierto que nuestro viajero es deudor a la interpretación "racionalista" de la arquitectura que propugnaba Viollet, pero no lo es menos que Vogüe puso de manifiesto las importantes incorrecciones historiográficas y geográficas del desarrollo de las Cruzadas sobre las que se apoyaba el arquitecto. Aun así nuestro autor, aunque "romanista" en cuanto al origen técnico de la bóveda, no era ajeno a aquellas seductoras y lejanas interpretaciones en torno al origen del arte medieval. De hecho, dirá, existen similitudes incontestables entre las escuelas siria y románica (fig. 6) que no pueden intelectualmente obviarse; pero su explicación no se concentra a partir del período de las Cruzadas, es mucho más amplia. Se trata de una "constante" de los primeros doce siglos de la era cristiana. Tal es el caso de la originaria influencia civilizadora directa de Siria y de sus arquitectos sobre los países bárbaros o germanos, o de la influencia - básicamente ornamental-- que peregrinos y cruzados sufrieron al encontrase con la rica imaginería de una cultura ya muerta ${ }^{31}$.

La aportación de Vogüe, más que poner de manifiesto las lejanas raices de la arquitectura de occidente consiguió integrar los estudios sobre Bi-

29 VIOLLET-LE-DUC, M., Dictionnaire raisonné de l'architecture francaise du xie àu xviè siècles. París, B. Bance, 1854-1868 (ed. facsimil. Paris. De Nobele. 1967. 10 vols.). vol. IX, págs. 480 y ss. Sobre la influencia del orientalismo sobre la restauración arquitectónica en Francia ver el artículo de P. L. Gallego Fernández, “Viollet le Duc: la restauración arquitectónica y el racionalismo arqueológico fin de siglo" así como el de J. Arrechea. "De la "composión a la arqueologia" arnbos en Restauración arquitectónica. Valladolid, Servicio de Publicaciones de la Universidad, 1991

30 Viollet-Le-DuC, M., Dictionnaire raisonnée... Vol. IX, págs. 480 . Un estudio detallado de esta larga obra de Viollet demuestra cómo el autor evoluciona hacia teorias cada vez más próximas a un "panorientalismo".

3t "La parte considerable que pertenece al Oriente en la génesis de las artes occidentales ha sido contestada, pero no es contestable" dirá Vogüe en Syrie centrale. Architecture civile et religieuse du ter au vie siècle. París, J. Baudry, libraire-éditeur, 1865-1877, 2 vols., Vol. 1, págs. 18-23. 


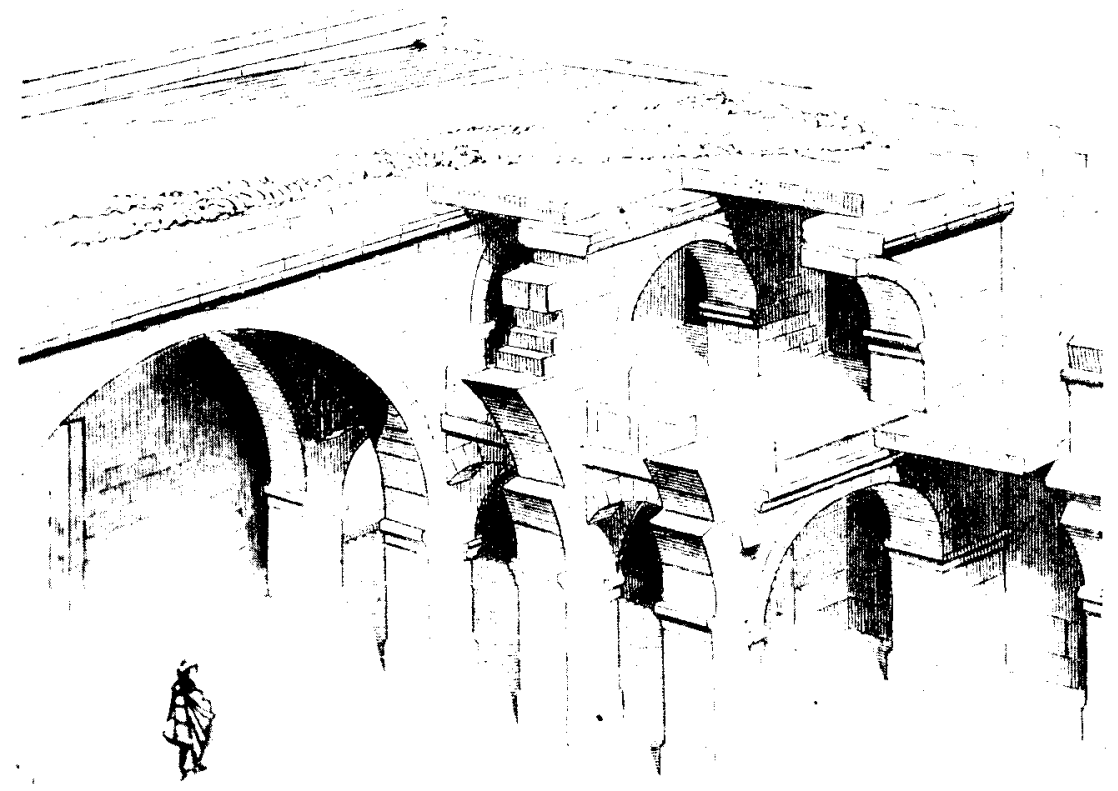

Fig. 5. Viollet. Estructura de iglesia siria. Dictionnaire... Vol. IX.

zancio y el Oriente Próximo como rama fundamental del medievalismo. Nace con ello una nueva reflexión sobre la amplitud y complejidad del arte occidental que medievalistas y orientalistas franceses, con representativas excepciones como las de Lasteyrie o Brutails, incorporaron a sus tesis. Choisy, M. Aubert, Dieulafoy o Diehl hicieron ince.pié en el problema sirio, pero el vienés Joseph Strzygowski le dedicó una de sus obras más completas y polémicas L'Ancien art chrétien de Syrie (París 1936). Mientras tanto el discípulo de Quicherat, Louis Courajod, gran maestro del orientalismo y sobre el que volveremos posteriormente, había difundido a través de las lecciones dictadas entre 1887 y 1896 desde su cátedra en L'Ecole du Louvre la idea de que toda la cultura artística clásica y occidental que dominó Francia ha sido una imposición de las clases históricamente dominantes. En su opinión, la «romanidad" nunca llegó a ser «... la expresión sincera del sentimiento nacional, ni la imagen completa e íntegra de la nación tomado en su conjunto" ${ }^{32}$. El poderoso y continuado germen oriental que constituyó occidente, nos dice, ha permanecido oculto bajo tra-

32 Courajod, Louis, Lecons professées a l'Ecole du Louvre 1887-1896). París, Alphonase Picard, 1899-1903, 3 vols, Vol. I, pág. 76. Estas lecciones fueron recogidas y publicadas tras la muerte del autor por Henry Lemonnier y Andre Michel. 


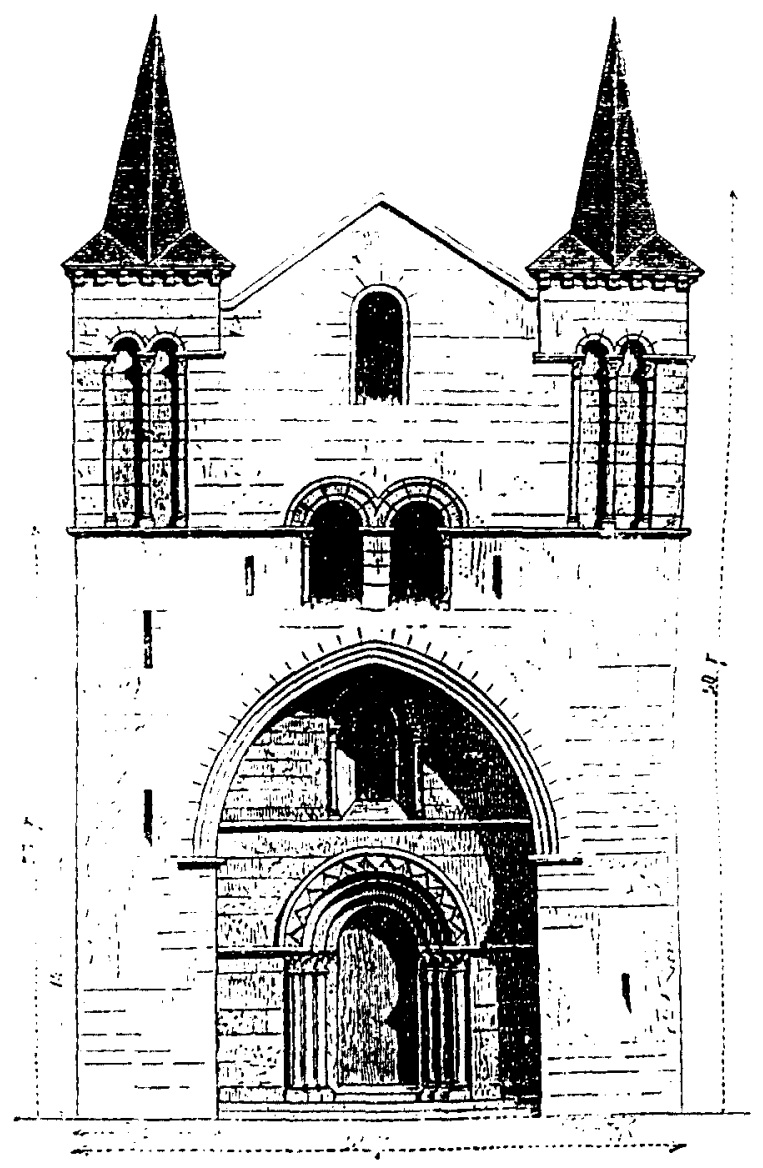

Fig. 6. VoGüE, Iglesia románica de Pontorson, en Syrie Centrale (1866-1875).

diciones y comportamientos ajenos a la cultura oficial, y profundamente vivo en el arte irlandés o en los temas ornamentales detectados en el denominado arte "bárbaro". Desde luego, el viaje de Vogüe o las tesis de Viollet sobre Siria estuvieron muy presentes en sus apasionadas y complejas descripciones de las fuentes del arte francés. Los argumentos, ya clásicos, suministrados por aquellos fueron ampliados por Courajod con la aportación de datos sobre la existencia de importantes colonias sirias en occidente a lo largo de todo el siglo $\mathrm{VI}^{33}$.

33 Courajod, L., Op. cit., págs. $324-330$ (vol. 1). 
Cuando Strzygowski publicó el mencionado L'Ancien art chrétien de Syrie la imagen de un arte occidental de formación ecléctica era un hecho comúnmente aceptado. A partir de la base suministrada por la historiografia francesa Siria se convierte en nuestro autor en un lugar de intercambio entre Oriente y el Mediterráneo ${ }^{34}$. Pero la propuesta historiográfica es distinta a la francesa. Entendido como lugar de paso por excelencia y valorado hasta estos momentos como fácil explicación de ciertos aspectos del arte mediterráneo, Strzygowski se propone devolver su realidad "oriental" al mundo sirio atrapado en interpretaciones arqueológicas clásicas. $Y$ asi van surgiendo del texto del profesor vienés, $y$ ante los ojos algo atónitos del lector moderno, hipótesis de grandes movimientos culturales ancentrales, influencias iranias, nórdicas, fascinantes viajes desde la Atlántida, mazdeísmo, cristianismo y budismo amalgamados en una gran religión originaria, de todo lo cual Siria es una mera frontera y receptáculo final. Es así, por tanto, que este arte no es original, recoge las influencias de un «interior» que se remonta a Irán y la India y crea la conexión por la que se difunden en Occidente elementos constructivos y ornamentales orientales ${ }^{35}$.

\section{ORIENTALISMO ARMENIO}

En 1920 el pintor armenio M. A. Fetvadjian expuso en París su colección de dibujos de arquitectura y arte armenio. El éxito de la muestra se debió a la extensión y fascinación por Oriente que ya se había convertido en verdadera moda de la cultura francesa. El prefacio al catálogo fue elaborado por Charles Diehl y en él se indicaba la importancia de Arme. nia como lugar de encuentro entre el mundo oriental o persa y el bizantino ${ }^{36}$. Cerrado el mundo sirio, atrapado en una interpretación "occidental". como más arriba señalé, en cierta forma hay que considerar esta fáscinante arquitectura armenia como la continuadora en la obsesión migracionista de la arqueología medieval europea. Además, esta vez los motivos parecian incuestionables.

En efecto, ante la claridad volúmetrica de edificios como las catedrales de Ani y Mren o la basílica de Ereruk, y, desde luego, ante la manifiesta

${ }^{34}$ StRzYgowski, Jospeh, L'Ancien art chrétien de Syrie, son caractère et son évolution d'aprés les découvertes de Vogüe et l'expedition de Princenton, la tacade Msachatta et le calice d'Antioche. París, E. de Boccard, éditeur, 1936, págs. 8.

${ }_{35}$ StRzYGowSkI, Jospeh, Op. cit. págs. 127 y 158-166.

36 MACLER, Fréderic, "L'architecture arménienne dans ses rapports avec l'art syrien", en Revue d'etudes armeniennes. París, 1920. págs. 253-263. También el texto de Charles Diehi "L'Architecture arménienne aux XI et vil siècles" en Revue d'etudes armeniennes. Paris, 1921 Tome I, fascicule 3, págs. 221-231. 
analogía de sus recursos técnicos y estéticos con el arte de occidente los historiadores parecieron aturdidos: pilares acantonados, bóvedas apuntadas, sistemas de nervaduras, cúpulas sostenidas por un sofisticado sistema de trompas, etc. Todo indicaba, o bien un desarrollo casi totalmente simétrico de la arquitectura occidental o, dada la cronología, un sistema de influencias por el cual nuestro arte medieval está directamente influido por el armenio (fig. 9).

Esta última opción es la que refrendó el conocido historiador Charles Texier, al que debemos las primeras noticias arquitectónicas sobre el reino de Armenia. Entre 1842 y 1852 Texier publicó los dos volúmenes de la Description de l'Arménie, la Perse et la Mésopotamie y ese mismo año publicaba en la Revue Générale de l'Architecture una descripción de la catedral de Ani que venía a reforzar las incipientes tesis orientalistas (figs. 7 y 8). Ciertamente esta catedral es una obra tardía (siglo x) en la compleja evolución de la arquitectura armenia cuyos orígenes están claramente emparentados con Siria y Mesopotamia, como fue posteriormente demostrado. Tal vez por ello Texier, al analizar dicha obra, vio básicamente en ella un monumento de «estilo ogival» influenciado por el arte bizantino, consecuencia del desarrollo de una cultura arquitectónica cuya importancia radica, según el historiador, en haber suministrado el tipo a la arquitectura alemana medieval a través de las migraciones del pueblo armenio hacia Polonia y Moldavia ${ }^{37}$. Similares tesis fueron utilizadas por Auguste Choisy en su conocida Histoire de L'Architecture (París 1899, 2 vols.) que en buena medida se inspiraba en la obra de Viollet. Para nosotros es interesante comprobar que Choisy utiliza tanto a Siria como Bizancio, Armenia o el arte musulmán como fuentes o indicadores del camino del desarrollo posterior del arte europeo. Oriente se integra en una interpretación occidentalizada en el que no está ausente la mítica referencia a las Cruzadas, pero tampoco a las migraciones de pueblos y formas. Es así como para Choisy existe una poderosa "corriente armenia" que rodeando el mar $\mathrm{Ne}$ gro se extiende por las provincias del Danubio hacia Escandinavia y posteriormente Inglaterra, Irlanda y Normandía. En Noruega, Choisy identifica sus conocidas iglesias de madera con esta poderosa influencia asiática que también está presente en la ornamentación ${ }^{38}$.

Las interpretaciones más interesantes del arte armenio estaban todavía

37 TEXIER, Ch., "Ruines d'Ani», en Revue Générale de l'Architecture. Paris 1842, págs. 1842 págs. 26-31 y 97-110. El texto está extraido literalmente de su Description de l'Arménie, la Perse et la Mésopotamie. París, Firmin Didot, 1842-1852, 2 vols., Vols. 1, págs. 115.

${ }_{38}$ Cholsy, A. Histoire de l'architecture. París, Gauthier-Villars, Imprimeur. 1899. 2 vols. (ed facsimil. Paris, Slatkine Reprints, 1987), Vol. II, págs. 84 y ss. 


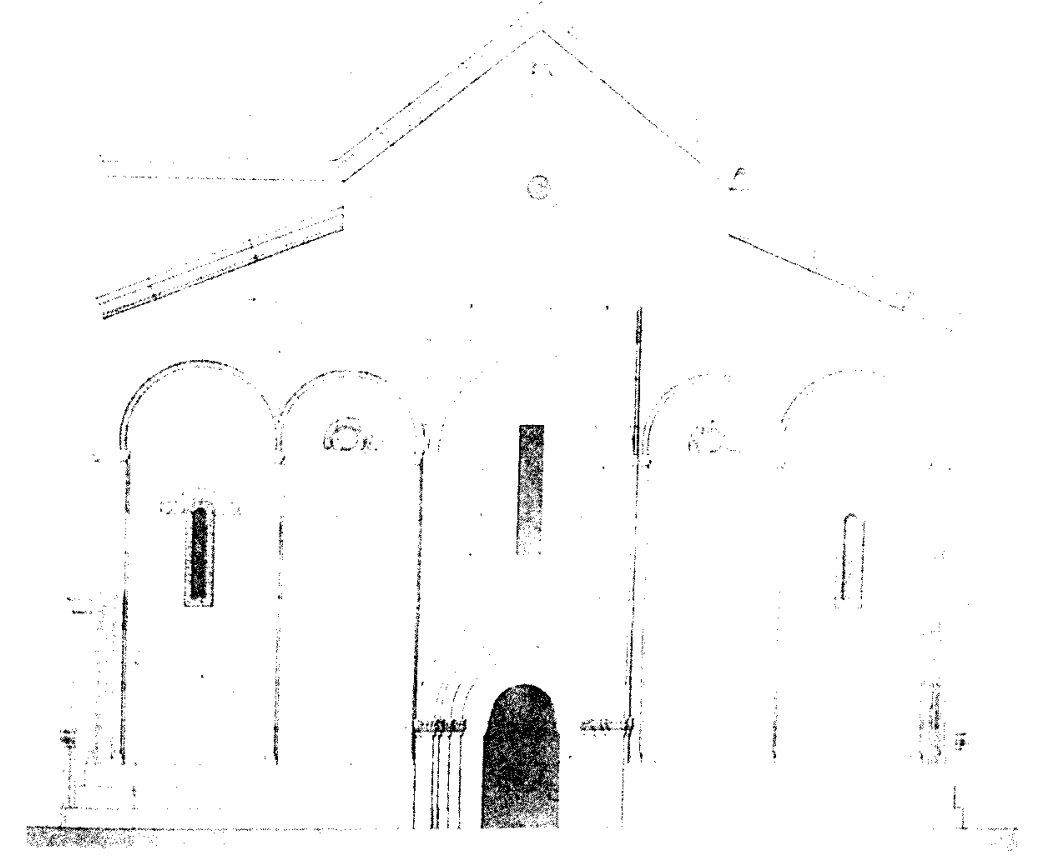

Fig. 7. TEXIER, Catedral de Ani restituida. En Description de L'Arménie... 1842.

por llegar. Dos personajes clave en la arqueología medieval y orientalista, Joseph Strzygowski y el que poco más tarde sería joven discípulo de Henry Focillon, el lituano Jurgis Baltrusitis, preparaban conclusiones divergentes. 

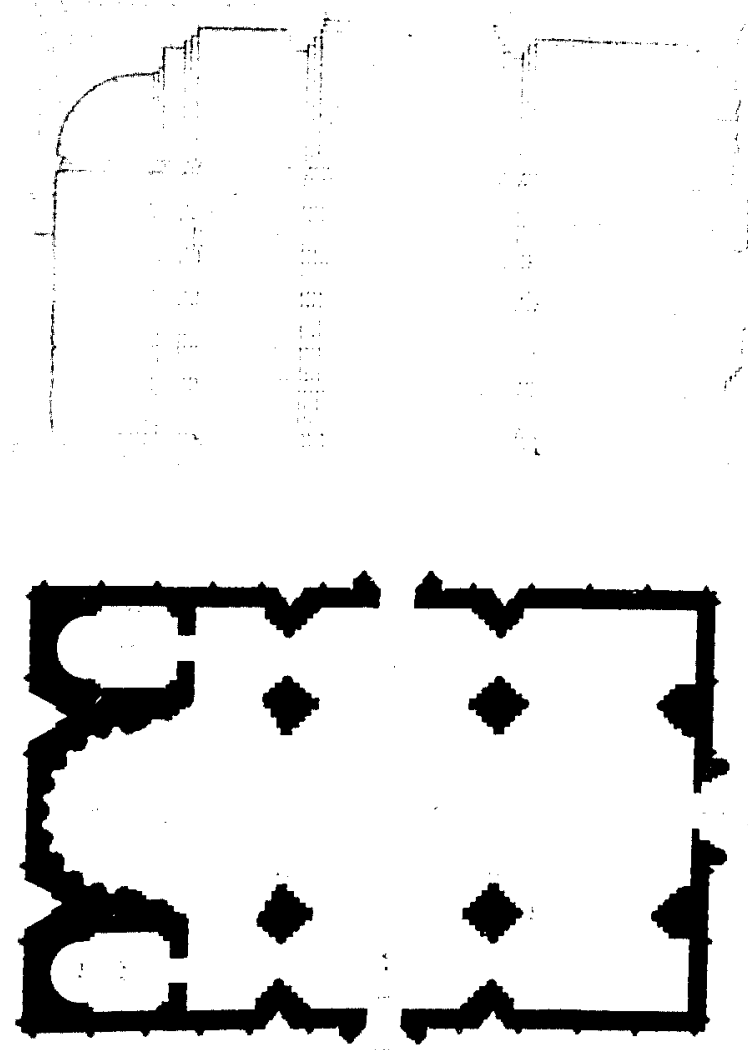

Fig. 8. Texier. Planta y seccion de lá catedral de Ani. En Description de / Arménie... 1842.

Las consecuencias radicales de las teorias de Texier y Choisy fueron extraidas a principios de nuestro siglo por Joseph Strzygowski que en 1918 publicó en Viena su Die Baukunst der Armenier und Europa. La gran documentación de estos dos volúmenes fue recogida en dos viajes rea- 


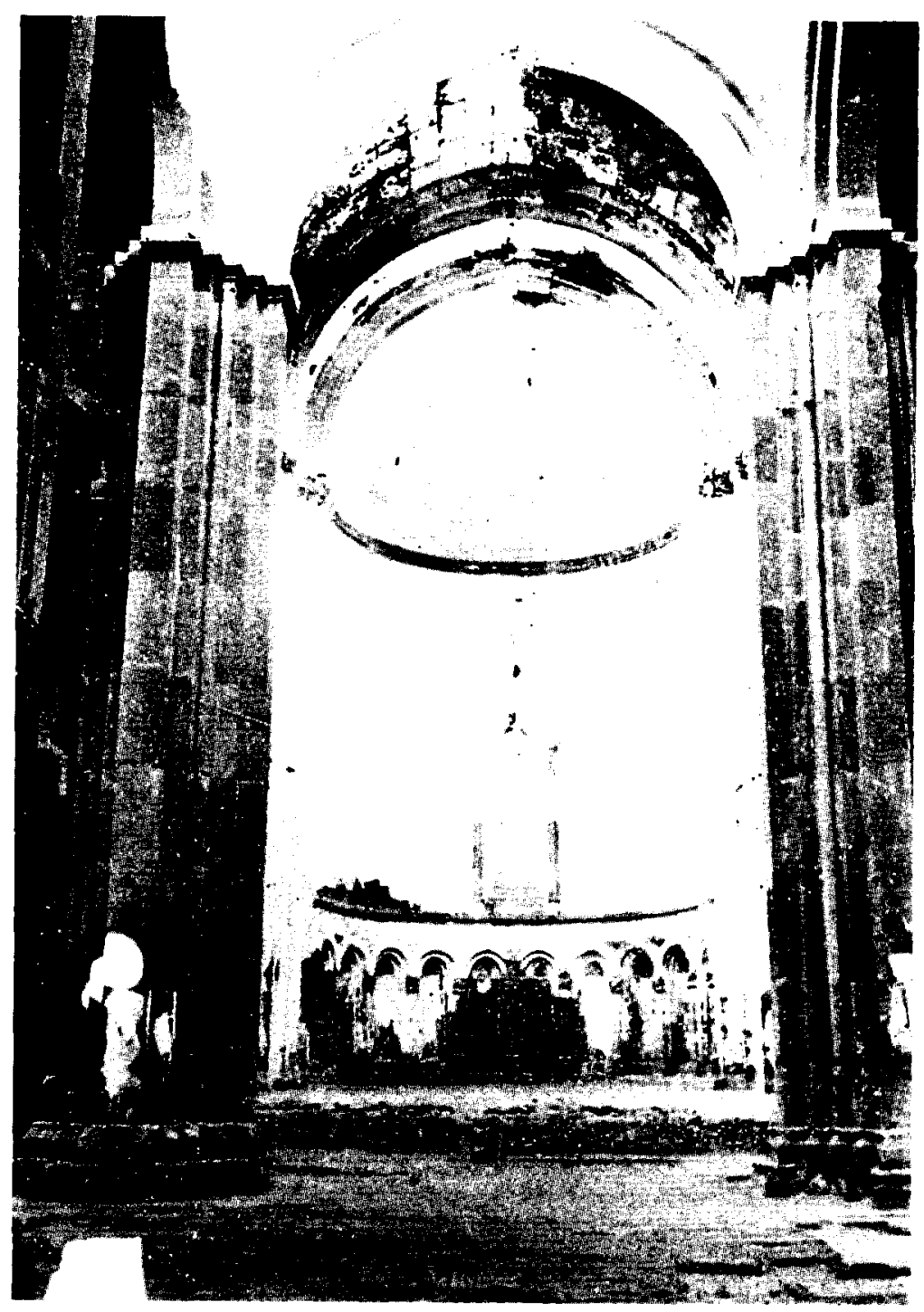

Fig. 9. Catedral de Ani: Foto actual.

lizados por el autor a principios de siglo ayudado por el arquitecto armenio Thoramanian. En aquel momento Strzygowski pretendió demostrar que la tradicional estructura de las iglesias armenias de cúpulas sobre pilares en planta cuadrada era un terreno sólido sobre el cual edificar la historia 
del arte cristiano medieval y solucionar el problema mítico de sus "orígenes" ${ }^{39}$ (fig. 10). En efecto, tanto él como su ayudante armenio opinaban que, con anterioridad a las sofisticadas soluciones en piedra, debió existir un período de experimentación tipológica del sistema de "baldaquino". La solución no podia por menos que ser radicalmente oriental. $Y$ es asi como Strzygowski hipotetiza la existencia de los milenarios "templos del fuego" iranios, en los que ya estaba presente este mismo sistema compositivo si bien con materiales menos duraderos, como el ladrillo, y que a su vez se basaba en prototipos anteriores de madera ${ }^{40}$.

Frente a esta actitud "fundamentalista» de Strzygowski, la cultura francesa través de Jurgis Baltrusaitis reconvertía el problema de los mitos originarios en un problema básicamente estético ${ }^{41}$. Así, en sus investigaciones sobre arquitectura oriental como los Etudes sur l'art médiéval en Geórgie et en Arménie (París 1929) o el no menos importante Le probléme de l'ogive et l'Armenie (París 1936), Baltrusaitis partía de la aceptación de la influencia oriental pero buscando, básicamente, establecer las diferentes bases estéticas que generaron la arquitectura armenia y románica (fig. 11 y 12). Desde esta óptica la arquitectura armenia es definida como un problema "plástico" frente al tradicional racionalismo "constructivo" occidental: "Debemos distinguir dos tipos de edificios, señala Baltrusaitis, uno se expresa por la organización racional, por la lógica, por la economía de los elementos, en donde cada uno juega un papel bien determinado en el conjunto. El otro acentúa los valores plásticos olvidando sacar partido de los constructivos" ${ }^{42}$. El sistema de oposiciones es claro y constante; frente a la planta jerarquizada y funcional cuyo exterior refleja el interior aparece la planta armenia, compleja, fragmentaria y yuxtapuesta, como un conjunto de edificios independientes aglutinados para formar un

\footnotetext{
39 Strazygowski, J., Die Baukunst der Armenier und Europa. Wien 1918, pág. 569.

40 La hipótesis sobre la importancia que pudieron tener los mencionados "templos del fuego" y su estructura de cúpulas sobre sistema de trompas ya fue estudiada en el Voyage en Perse de M. Eugène Flandin, peintre, et Pascal Coste, architecte attachés a l'Ambassade de France en Perse, pendant les années 1840-1841. París, Gide et J. Baudry, Libraires-éditeurs, 1853, 5 vols., 4 de atlas.

41 La polaridad Strzygowski/Baltrusaitis como autores que justifican la historia de la arquitectura desde el oscuro mundo de unos migratorios "origenes" o desde la plástica sólo es metodológicamente exacta desde una óptica historiográfica. Desde luego al primero sí le interesa una interpretación estética de los monumentos, pero la vinculación a la modernidad del profesor vienés está marcada por su acercamiento a las corrientes expresionistas alemanas con toda su carga de esoterismo y primitivismo. El problema de la arquitectura expresionista ha sido magníficamente estudiado en el artículo de Marcello Fagiolo. "La Catedral de Crista!. La arquitectura del expresionismo y la tradición esotérica", en El pasado en el presente. Barcelona, Gustavo Gilli. 1977, págs. 199-258.

${ }_{42}$ Baltrusaitis, Jurgis, Etudes sur lart médiéval en Geórgie et en Arménie. París, Libraire Ernest Leroux, 1929 (Préface de Henri Focillon), pág. 81
} 


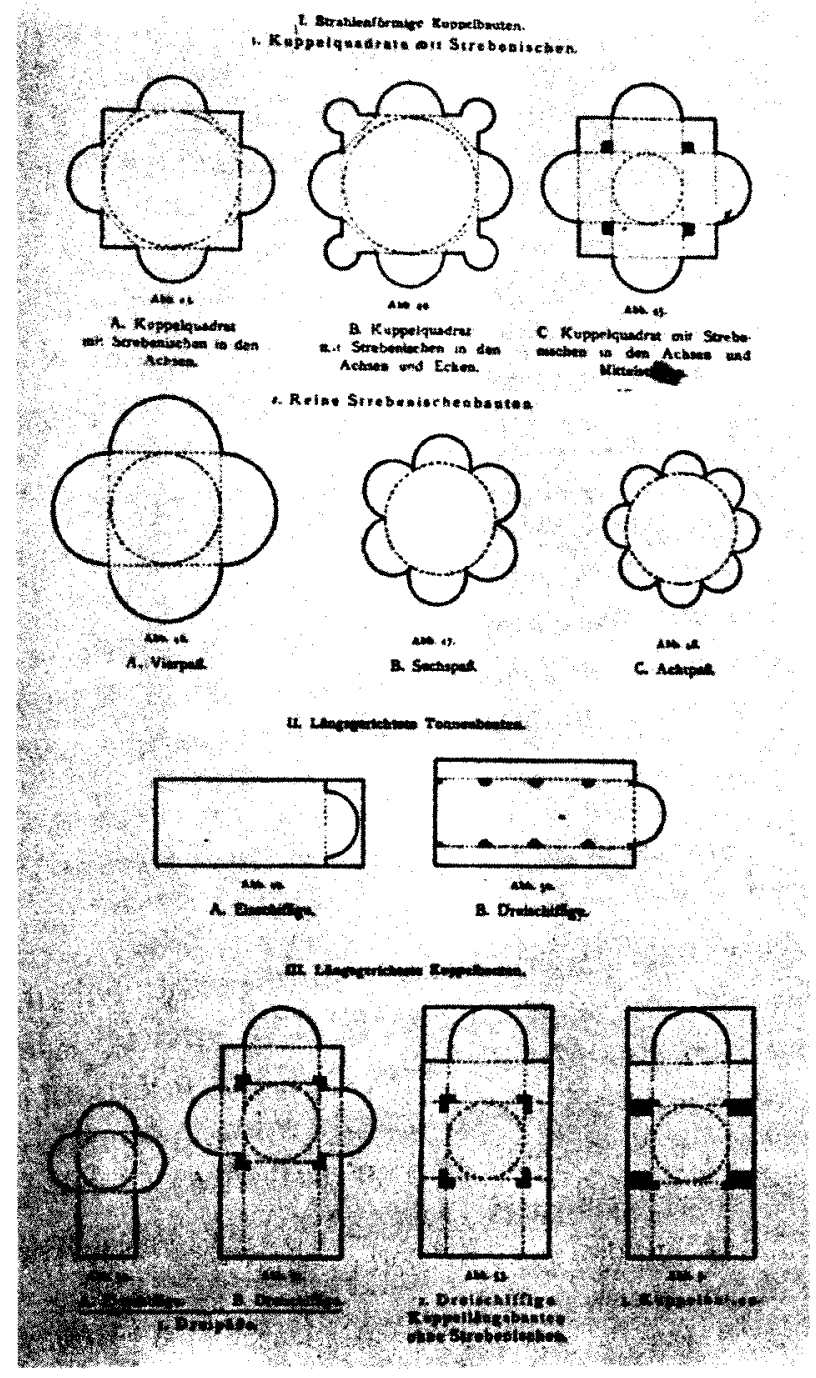

Fig. 10. StRzygowski. Tipos de iglesias armenias. 1918.

espacio interior que es ajeno a la sencilla y regular volumetría exterior del edificio. Este hecho y su trasposición a la organización espacial, o al sistema construtivo, constituye lo que Baltrusaitis denominó el "atectonismo" arquitectónico armenio en donde predominan los elementos centri- 


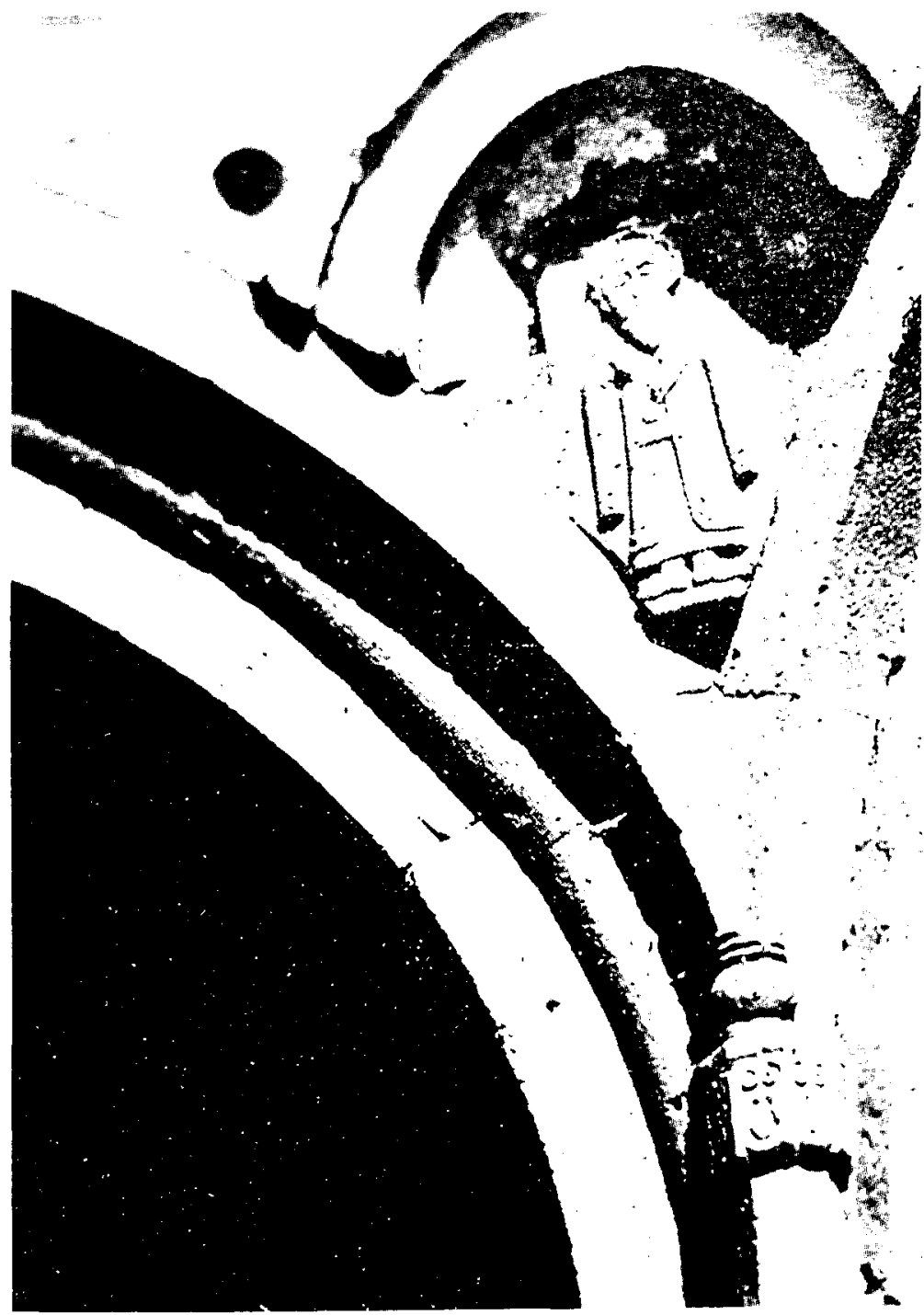

Fig. 11. Trompa de la iglesia armenio-georgiana de Kourmourdou (Siglo $x$ ).

fugos o de desorden atados en última instancia por poderosas geometrías exteriores ${ }^{43}$.

43 Baltrusaitis, J. Op. cit, págs. 82-86 


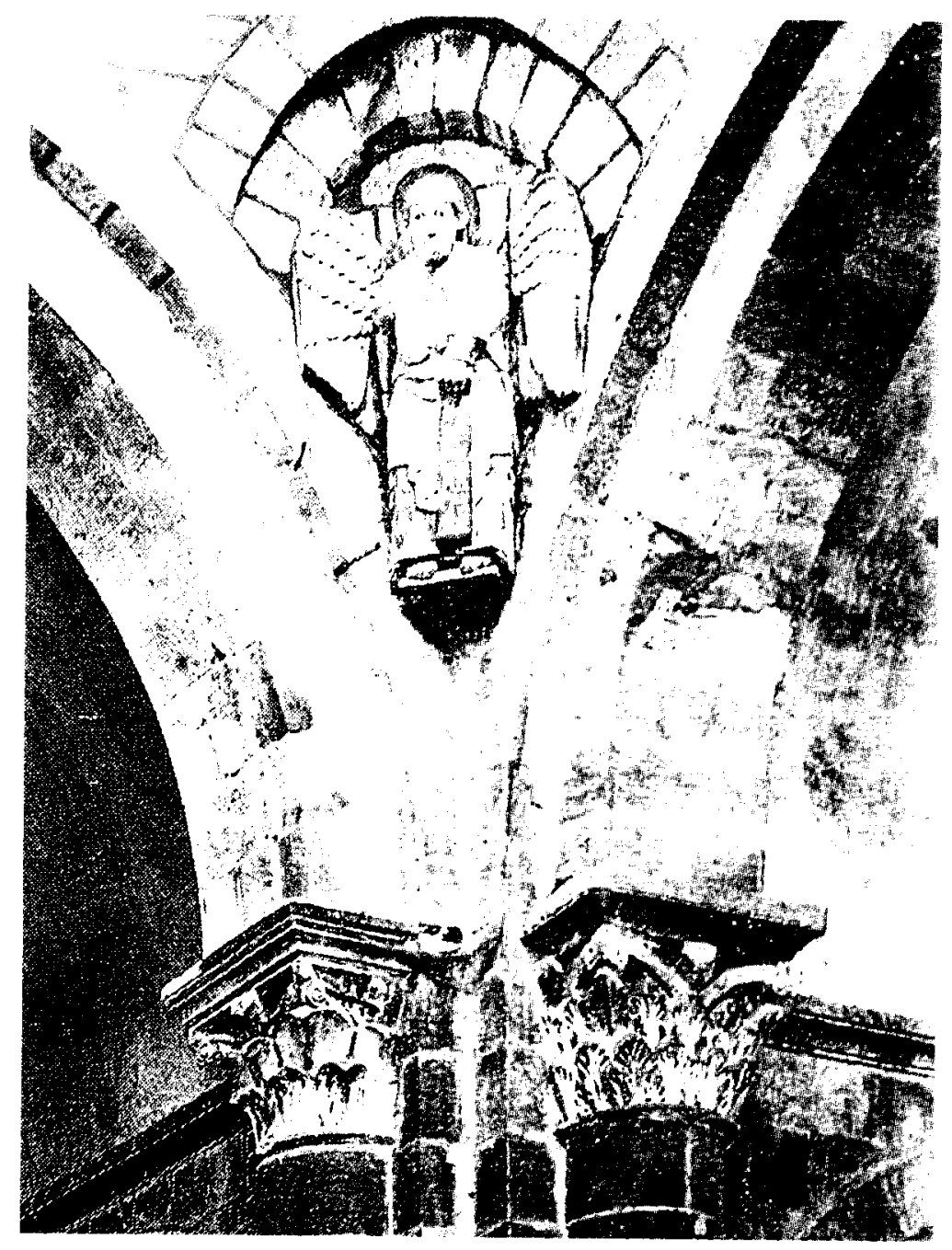

Fig. 12. Trompa de la iglesia de peregrinación de Conques.

El autor aplicará esta misma interpretación al segundo gran período de la arquitectura armenia (siglos $x$ a $\times 11$ ), momento en el que hacen su aparición complejos sistemas de bóvedas de crucería que parecen establecer una clara analogía con el gótico occidental (fig. 13). De nuevo, la extraña similitud es analizada por Baltrusaitis insistiendo en la diversidad de los intereses plásticos de Armenia y Europa. Si es cierto que en esta 


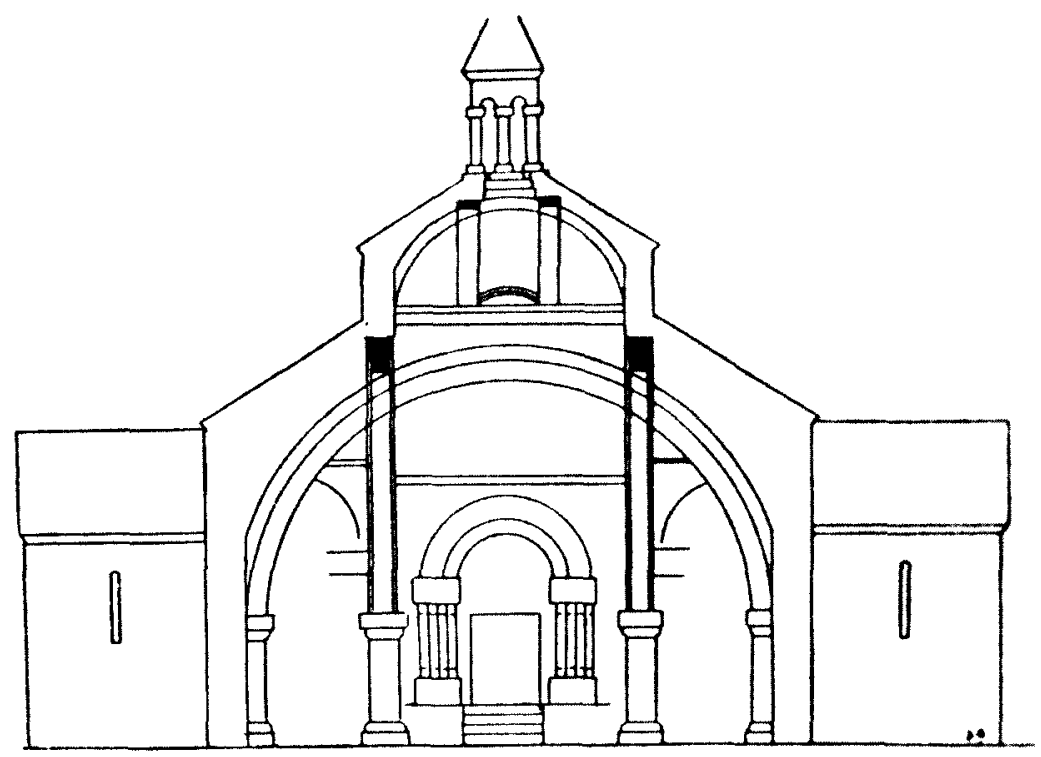

Fig. 13. Baltrusaitis. Estructura armenia de bovedas nervadas. Iglesia de Hahpat (siglo $\times 1)$.

arquitectura oriental se revela un poderoso afán lógico-constructivo, no lo es menos que el sistema de ogivas empleado fragmenta y diversifica el espacio entrecruzándose en forma paralela o perpendicular a los muros. Las superficies resultantes son tratadas con infinita diversidad utilizando bóvedas abombadas o triangulares y cortadas en ángulo recto. Aun sin perder la unidad esta arquitectura se diferencia estéticamente de la "solución más compleja y sutil que se elabora en Gccidente" y que, partiendo de la bóveda de aristas romana, finaliza por crear una disposición flexible que inspira una osamenta dúctil, cercana a un orden "teórico" ${ }^{44}$.

\section{DEL ORIGEN DEL LENGUAJE A LA EXPLICACIÓN DE OCCIDENTE}

Sin embargo, tanto Siria como Armenia enterididas como posible origen del arte occidental, como cuna de las formas, son sólo débiles mues-

44 Baltrusaitis. J., Le problème de l'ogive el l'Armenie. París, Librairie Ernest Leroux, 1936. Fundamentalmente págs. 47-61. 
tras que se recortan contra explicaciones y sintesis mucho más generales y deudoras a ciencias como la lingüistica, la antropología o la arqueología. La evolución historiográfica del arte medieval, y su descripción arquitectónica, no es separable de este problema.

A finales del siglo xvIII Sir William Jones, erudito inglés, estudiante de hebreo, árabe y persa y posteriormente nombrado Juez del Tribunal Supremo de Calcuta, hizo una serie de descubrimientos maravillosos para la historia de la lingüística. Durante años se habia interesado por la lengua literaria y sagrada de la India, el sánscrito, y en 1786 llegó a conclusiones definitivas en torno a su valor. Para Jones el sánscrito es poseedor de una estructura perfecta, más rica que el griego y el latín, y con una afinidad tan estrecha con estas lengüas tanto en las raíces de los verbos como en las formas gramaticales «... que ningún filólogo podría examinar las tres sin pensar que han surgido de una fuente común que, quizás no exista ya" ${ }^{45}$.

El trabajo de Jones, considerado fundacional, implicaba un conjunto de consecuencias que no tardaron en ser advertidas, pero no tanto en Inglaterra como en el naciente romanticismo alemán, y a su cabeza los hermanos Schlegel. Así, mientras August traducía el Bhagavadgita y con posterioridad el Ramayana su hermano Friedrich publicó en 1808 su conocidísimo Über die Sprache und Weisheit der Indier ("Sobre la lengua y la sabiduría de los indios"). Extrapolada en forma metafórica a los gramáticos hindús, Friedrich Schlegel alababa la flexibilidad de los sistemas de "raíces" del sánscrito, modelo de las denominadas lenguas uflexionantes" entre las que obviamente se encontraban las lenguas europeas como alemán, griego o latín. En consecuencia, existen entre Oriente y Occidente un conjunto de lenguas, de impresionante similitud con el sánscrito cuyo parecido “... se encuentra no solamente en el gran número de raices comunes, sino que se extiende hasta la estructura interior de estas lenguas y su gramática» ${ }^{46}$.

Las consecuencias de todo ello fueron impresionantes. Antropólogos y lingüistas veian en las lenguas “orgánicas", caracterizadas por su sis-

45 Citado por Renfrew Colin, en Archaeology and languaje. The puzzle of Indo-europeans origins. London. Jonathan Cape Ltd. 1987 (cito por la ed. española. Barcelona, Critica, 1990, pág. 17).

46 Cito a través de la edición francesa de 1837: Essai sur la langue et la philosophie des indiens. París, Parent-Desbarres, Editeur, 1837, pág. 11. Sobre la historia de la lingüística y sobre la importancia que adquirió el "descubrimiento" del sánskrito ver MouniN. G., Histoire de la linguistique des origines au xx siècle. Paris, PUF, 1985 (Primera ed. de 1967). Fundamentalmente, págs. 156-218. 
tema de radicales o utilización del verbo "ser", una capacidad especial para la reflexión filosófica; por ello el filólogo francés Chézy se sintió capaz de plantear en 1822 la relación de afinidad entre la metafísica platónica y los Oupanichads o "textos secretos" de los Vedas, opinión que fue compartida posteriormente por el antropólogo Adolphe Pictet que veía en la India. Grecia y Alemania los lugares en los que habia cobrado especial maduración un gran lenguaje originario perfectamente preparado para la reflexión metafísica y filosófica ${ }^{47}$.

Por otro lado, el desarrollo, gracias a Bopp y Rask, de la denominada "gramática comparada" posibilitó la investigación en torno al gran lenguaje "originario" y común que parecia desprenderse de las tesis anteriores. El primero de ellos lo intentó en 1816 con la publicación de una obra fundamental para la lingüistica moderna: Ueber das Conjugationssystem der Sanskritsprache in Vergleinchung mit jenem der griechischen, lateinischen, persischen und germanischen Sprache ("Sobre el sistema de conjugación del sánscrito en comparación con el griego, latín, persa y alemán") en donde el autor buscaba remontarse a las fuentes primigenias del lenguaje, a las primeras palabras, a las raices monosilábicas aisladas y ya dotadas de sentido (es decir, no pervertidas por una utilización arbitraria del signo), a través de la morfología transparente de la lengua más antigua conocida ${ }^{48}$. Con los trabajos de los hermanos Schlegel, Bopp, Rask o Chézy se consolidaba no sólo un método filológico de transcendental importancia, sino un interés cultural hacia oriente sin el cual es difícilmente comprensible la mentalidad del siglo.

Hacia 1850 el interés orientalista se reduplica con la aportación de la denominada "arqueología lingüística». Los filólogos, en efecto, comenzaron a investigar no sólo el ancestral lenguaje común de oriente y occidente sino al pueblo que lo portaba. Surge así la idea del pueblo rindoeuropeo" o "ario", dividido en la actualidad en multitud de diferentes ramas pero cuya unidad idiomática originaria hace pronto pensar en una similar unidad racial y cultural. Su rastreo y reconstrucción teórica se hizo posible gracias al "método comparado» entonces en su apogeo. Y así, lo mismo que se pudo elaborar un "protoléxico" indoeuropeo estudiando los

47 Chezr. Mr. de, "L'ermitage de Kandoun en Journal asiatique. París, Juillet 1822, págs. 310. PICTET, Adolphe, Les origines Indo-européennes ou les aryas primitifs. Essai de paléontologie linguistique. Paris, Librairie Sandoz et Fischbacher, 1877, 3 vols. (Segunda ed.). Prim. ed. de 1859, vol. III, págs. 296-297. M. de Chézy fue heredero directo de la escuela orientalista francesa formada en el Collège de France en torno a Sylvestre de Sacy en donde estudiaron sánscrito los Schlegel, Humboldt o Bopp.

4B Mounin. G., Op. cit., pág. 176-177. 
elementos comunes de palabras afines concretas existentes en diferentes lenguas, se intentó reconstruir la vida espiritual, social, religiosa o técnica, e incluso la patria originaria de lo que ya empezaba a ser una raza mítica. La gran obra de Adolphe Pictet Les origines Indo-européennes ou les aryas primitifs. Essai de paléontologie linguistique (París 1859) constituye una de las mayores construcciones y utopias lingüísticas de la historia. La sofisticada reconstrucción da paso, a través de matizadas comparaciones entre lituano, gaélico, latín, griego, sánscrito o alemán antiguo, a un sistema de raíces comunes por las que Pictet justifica desde la estructura familiar y económica hasta el desarrollo técnico, vida espiritual o medio geográfico originario del pueblo ario ${ }^{49}$. No es menos relevante que todas estas tesis apoyasen la idea de un pueblo "privilegiado" y motor de la historia, dotado por el lenguaje para la filosofía, amante del progreso y de la renovación, y en el que prodomina un equilibrio armonioso de facultades y aptitudes ${ }^{50}$.

En absoluto es de extrañar que los estudios antropológicos que se inician en este período, y que intentaban explicar la evolución del hombre, rezumasen buenas dosis de filosofia racista. Un caso ejemplar es el del romántico legitimista y con posterioridad Embajador en Teherán, Conde de Gobineau, en el que sintetizó la metafísica lingüística alemana, la antropología científica iniciada a finales del XVIII en la obra de Camper y su personal fascinación por Oriente. Aunque su obra literaria e historiográfica está siendo actualmente sometida a revisión, su trabajo más conocido el Essai sur l'inégalité des races humanes (París 1853-1855) ha sido considerado el inicitador mecánico de las teorías racistas que desembocan dramáticamente en los años treinta del presente siglo ${ }^{51}$. Ciertamente Go-

49 Según Pictet este "Urheimat», o patria originaria, es la provincia de Bactriana en la meseta norte de Irán. Ver Les origines Indo-européennes ou les aryas primitifs. Essai de paléontologie linguistique. Paris, Librairie Sandoz et Fischbacher, 1877, 3 vols. (Segunda ed.) Prim. ed. de 1859, vol. I, págs. 52-56. Pictet trabajó profundamente condicionado por la idea de que el sánscrito era la lengua indoeuropea más primitiva de lo que se deducía que occidente tenia que haber recibido sus invasiones de la India o zonas próximas.

El sentido y posición de esta patria originaria fue muchas veces modificado a lo largo del siglo y medio que duró la polémica indoeuropea. Asi, aparecieron las estepas rusas, Lituania, Alemania o los paises escandinavos como posibles patrias de este pueblo. En cualquier caso todos estaban dispuestos a conceder que la división en las dos grandes ramas, oriental y occidental, se produjo en las mesetas próximas a Armenia, Anatolia o Persia.

Para un resumen actualizado de la situación me remito al ya mencionado trabajo de $C$ Renfrew y al más antiguo de BosCH-GimperA, El problema indoeuropeo. México, Fondo de Cultura Económica, 1989, (1 ed. 1960).

so Pictet. Op. cit., pág. 273, 296 y 538 (Vol. III).

s) La obra de Gobineau fue sumamente apreciada en Alemania. Sobre el tema ver GARCí Calderón F., Europa inquieta. Madrid, Ed. Mundo Latino, 1926, págs. 205-214. 
bineau no pretendia demostrar la superioridad empírica de un hombre sobre otro, sino que en realidad buscaba utilizar el mecanismo racial de interpretación histórica para recrear la poética epopeya de una humanidad en decadencia desde hace más de tres mil años.

El primer aspecto llamativo de su teoria es la crítica al concepto ilustrado de decadencia política basada en criterios tales como la "irreligión", el "lujo", el "mal gobierno" o la "corrupción de las costumbres y las instituciones". Frente a ello Gobineau levanta una historia racial de la decadencia que se inicia en aquel remoto origen en el que las razas no habían sido sometidas a ningún tipo de mezcla, y permanecian atadas a su tierra originaria. Sin embargo, para que estos pueblos llegasen a un estado "civilizado", para originar la propiedad, las ciudades, el comercio o las naciones era imprescindible romper aquellas barreras ancestrales, era necesaria la invasión y el predominio político, bélico y finalmente civilizador de un determinado pueblo sobre otros, lo que implicaba unas ciertas dosis de mezcla racial con los pueblos dominados que ayudaba a engrandecer su cultura. Es aquí donde se esboza el inicio de la degeneración de las naciones; en la medida en que el núcleo originario mantenga su germen vital y sus principios, dice Gobineau, aquella permanecerá a salvo, y su desaparición se producirá, sin embargo, cuando el exceso de las consecutivas mezclas lleguen a invadir y borrar los valores del germen civilizador primigenio ${ }^{52}$.

La raza es, pues, un agente histórico de primer orden. Su origen y facultades no son en ningún caso idénticos, pues existen tribus intelectualmente incapaces de romper su aislamiento originario y otras que son por naturaleza creadoras de estados. Entre estas últimas la más importante es, obviamente la raza «aria», creadora de sofisticadas lenguas, de grandes fuerzas políticas y militares, único pueblo en el que son verdaderamente activos los modernos conceptos de "historia" y de "libertad" $y$ en el que, por último, domina una noble belleza todavía presente en la estatuaria griega ${ }^{53}$.

\footnotetext{
2 Gobineau. M. A., Essai sur l'inégalité des races humanes. Paris, Librairie de Firmin Didot, fréres. 1853-1855, 4 vols. Vol. I, págs. 36-53.

${ }_{53}$ "... los héroes de La lliada, los guerreros escandinavos, todos ellos fantasmas gloriosísimos de las razas más bellas, hoy desaparecidas, ofrecian una imagen más brillante y más noble de la humanidad; eran sobre todo agentes de la civilización y de grandeza, más activos, más inteligentes, más seguros que los pueblos mestizos de la época actual y, sin embargo, ya no eran puros" Gobineau. Op. cit, Vol. ill, pág. 123.
} 
TEORIA RACIAL Y ARQUITECTURA: VIOLLET Y COURAJOD

Es fácil comprender que cosmovisiones históricas tan atractivas influyesen en la apreciación de la historia de la arquitectura. Si la antropología demostró la existencia de un pueblo que ha generado y trasladado el lenguaje, la filosofía o la política, no se está muy lejos de pensar que ese mismo pueblo privilegiado haya podido hacerlo con la técnica o la arquitectura. $Y$ de nuevo Viollet-le-Duc, siempre ávido por integrar en su concepto de arquitectura las aportaciones de otras ciencias, nos suministra la clave. Fue en uno de los últimos trabajos del arquitecto, la di-

\section{HISTOIRE}

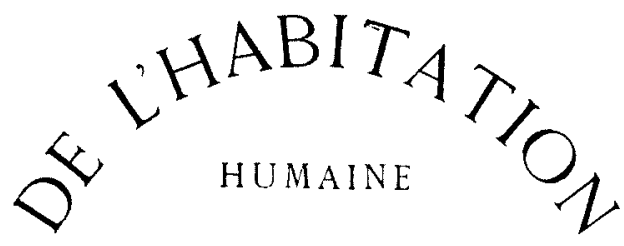

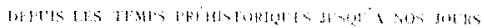

IFX I L E OESSES

VIOLLET-LE-DUC

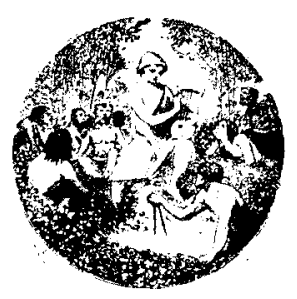

PRRIS

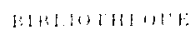

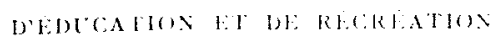

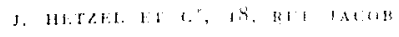

Fig. 14. VIOLLET, Portada de Histoire de l'habitation humaine (1875). 
vulgativa Histoire de l'habitation humaine (1875), en donde se hizo explícita una relación mecánica entre raza aria e historia de la arquitectura. Ya el pequeño grabado de la portada de este misterioso libro es una promesa de lo que no espera en el texto: el canto a la superioridad intelectiva de la raza blanca. El grabado lo narra claramente pues, rodeando a Orfeo que se acompaña de la lira, se reúnen hombres de diversas razas; todos ellos permanecen embelesados ante su voz, pero uno de ellos, el ario, es capaz de traducir con el compás la armonía musical en armonía geométrica a través de figuras elementales (fig. 14). Viollet, por tanto, nos promete un pueblo creador, que fascinará a uno de los dos protagonistas de la obra, Epergos, espíritu inquieto y apóstol de la invención, que recorrerá la obra contemplando los avances arquitectónicos del pueblo ario a lo largo de sus migraciones y polemizando constantemente con su antagonista, Doxi, espíritu del orden y la estabilidad (fig. 15).

La casa aria primigenia, próxima al Himalaya, era sencilla pero a su vez profundamente superior a las guaridas improvisadas de los primeros hombres. Construida en madera el "hom" o ario había dejado en su vivienda las muestras de una racionalidad superior a través de una "figura" característica, el triángulo, cuyas virtudes técnicas y estéticas Epergos no deja de alabar ${ }^{54}$ (fig. 16). Con posterioridad, y por influencia de este genio protector, los arios modificaron la construcción sin modificar la lógica: esta vez se realizó en piedra. Establecido el principio sólo había que extenderlo adecuándolo al medio físico o cultural de que se tratase. Es así como Viollet, remitiéndose al texto de Gobineau, hace surgir el valor

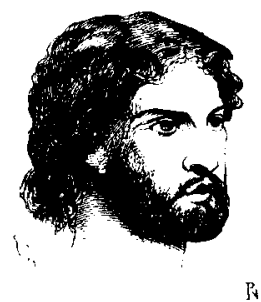

Ps

Fig. 15. VIOLLET. Histoire... El «ario".

s4 VIOLLET-Le-DuC, Histoire de l'habitation humaine. Paris, Bibliothèque d'Education et de Récréation, 1875 (existe ed. facsimil. Paris, Berger-Levrault, 1978), págs. 18-25. 


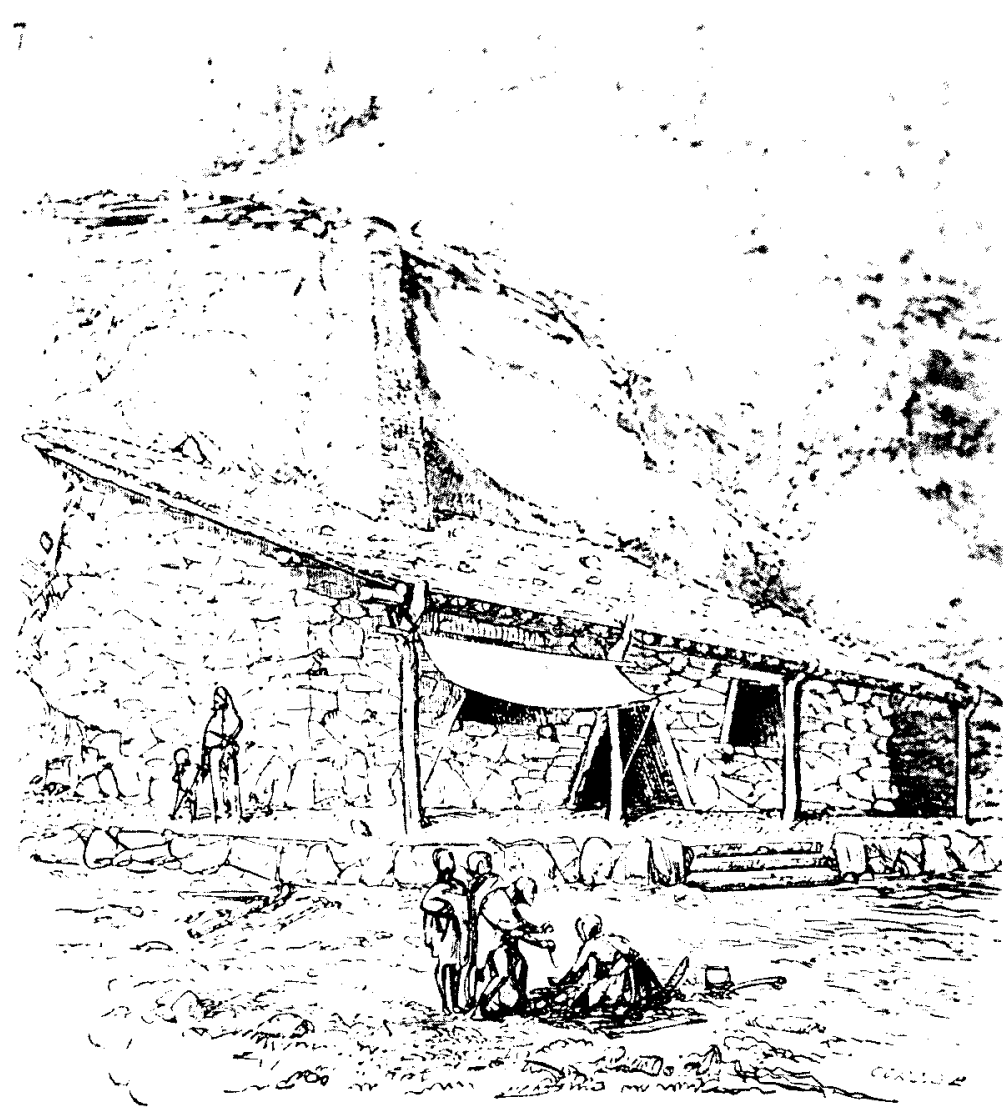

Fig. 16. Viollet, Histoire... Casa aria primigenia

positivo de las "mezclas", o lo que hoy día denominaríamos los estilos, que son sólo el resultado de la variación histórica del principio.

Por tanto, cuando estos mismos arios se extendieron desde sus remotos refugios hacia las fértiles tierras del Indo trasladaron con ellos su manera de entender la arquitectura haciendo siempre predominar la lógica triangular tanto en la idea general del edificio como en las jambas de puertas y ventanas, si bien con la necesaria variación en los materiales (fig. 17). Esta misma variación puede contemplarse en el gran ramal oc- 


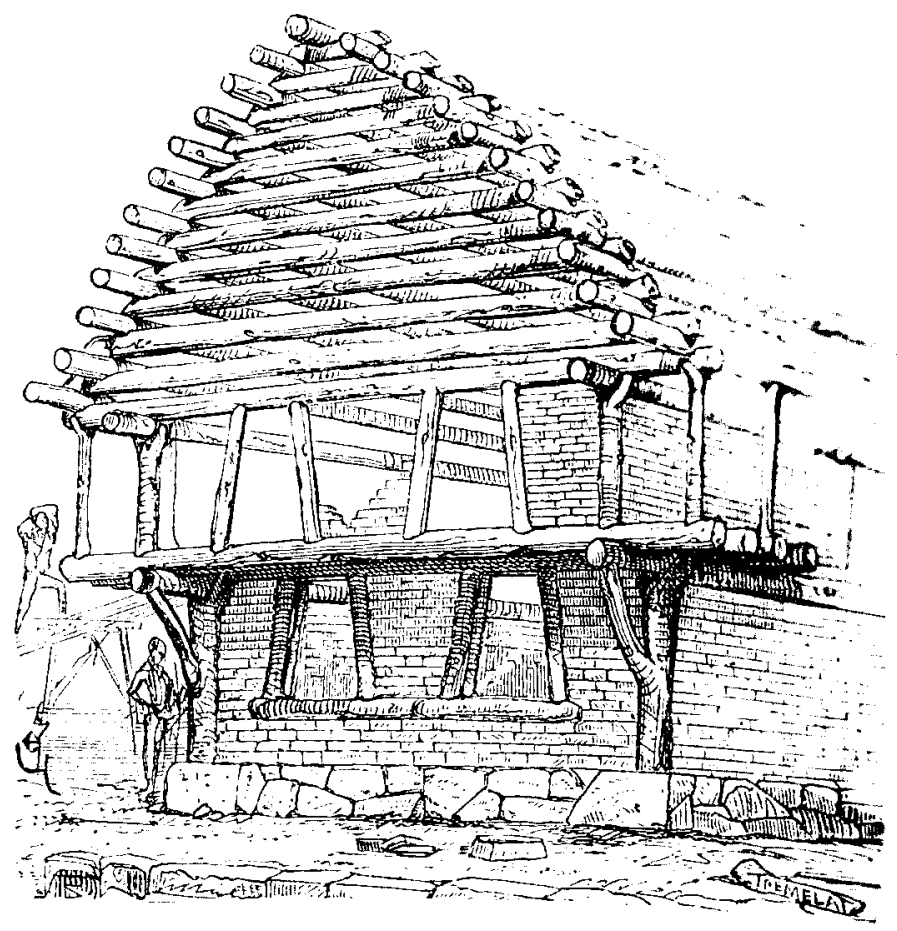

Fig. 17. Viollet Histoire... Casa aria del Indo

cidental de la migración aria. La gran arquitectura asiria no es más que el resultado de la mezcla del saber organizativo de los indoeuropeos con la sensibilidad de los pueblos semita y egipcio más aptos que aquel para la práctica de las artes. Pero también es un cambio estilístico o, siguiendo las tesis de Viollet, el resultado de la adecuación de la arquitectura a un nuevo medio caracterizado por la ausencia de la madera, la humedad y las altas temperaturas, que marcó la aparición tanto del arco de medio punto como de la posterior bóveda de cañón ${ }^{55}$.

Como es lógico esta historia no tienen final; resulta atractivo rastrear los dibujos de Viollet y contemplar como intenta convencernos de la exis-

55 Según Viollet, cuarido los habitantes de Mesopotamia vieron que la estructura de madera adintelada se curvaba o quebraba por el peso de la arcilla protectora del sol, "inventaron" la bóveda que en un principio se sostenía por cimbras de caña permanentes. Con posterioridad este cimbrado fue sustituido por el arco de ladrillo con lo que se consolidaba el sistema. VIOLLETLE-Duc, Op. cit., págs. 136 y ss. 
tencia de una vieja tradición constructiva de madera a la que no fueron ajenos pueblos como los jonios, griegos o escandinavos (fig. 18 y 19), y que lentamente se fue fusionando con sistemas constructivos basados en piedra o ladrillo sin perder su lógica primigenia. Viollet nos explica la historia de la arquitectura a través de una explicación racial; él mismo sería el último arquitecto "ario", o ¿acaso podemos evadir la identidad figurativa entre la mencionada casa del Indo y los proyectos del arquitecto?

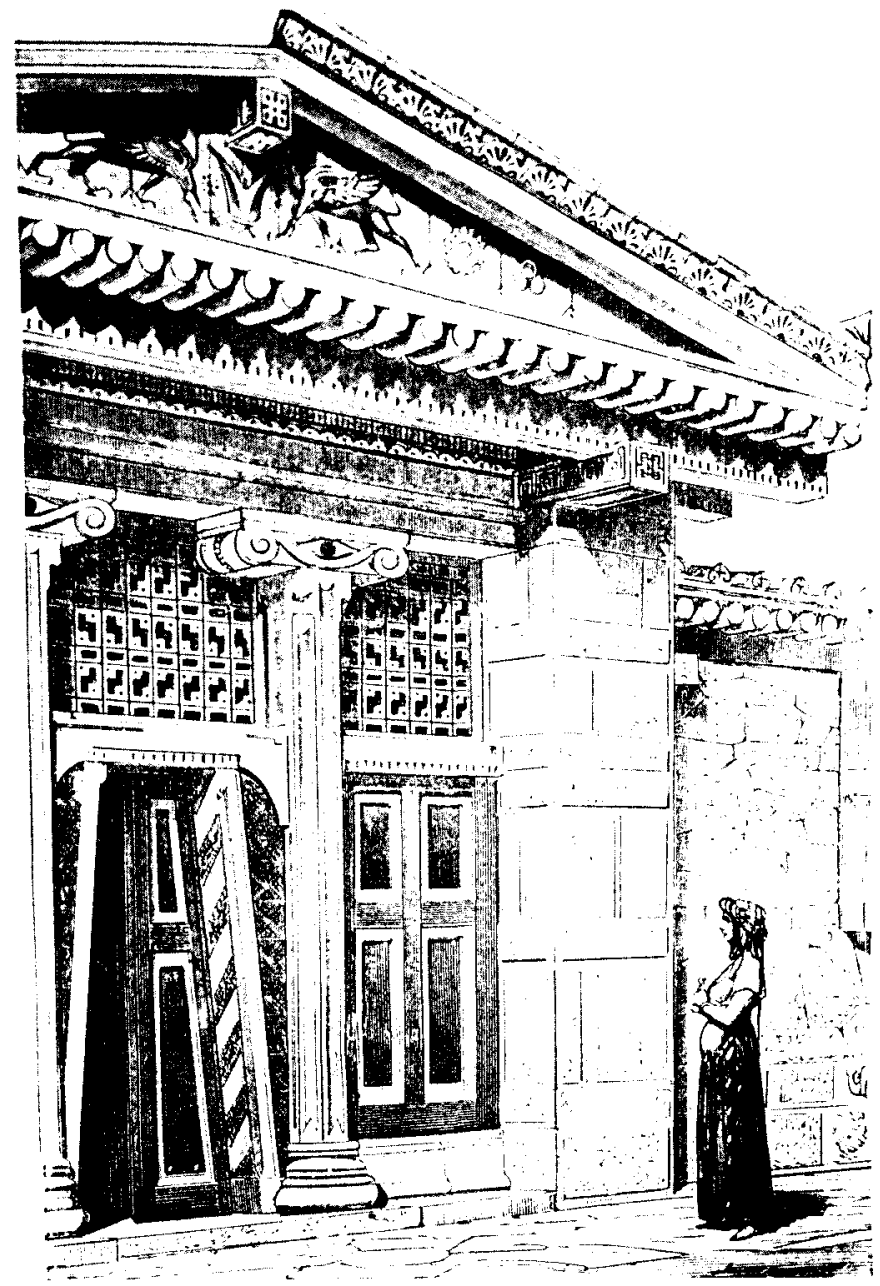

Fig. 18. Viollet, Histoire... Casa Jonia. 


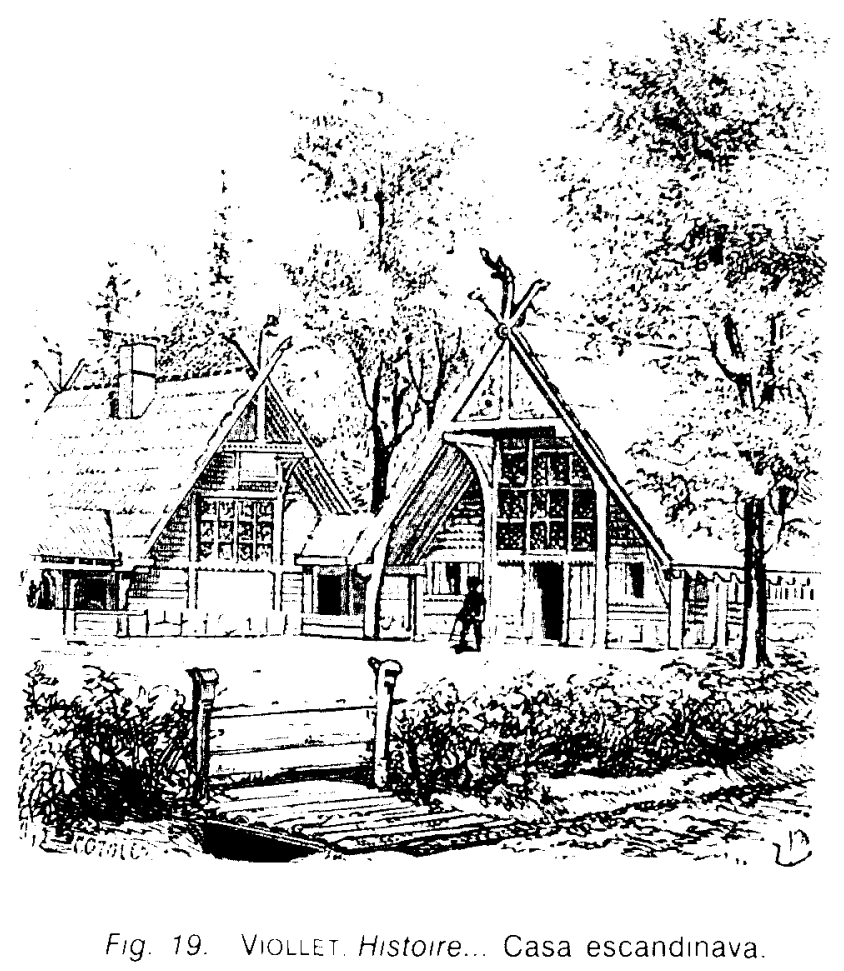

Tal vez estas tesis fueron elaboradas demasiado tempranamente, 0 bien el tipo de edición - de carácter divulgativo - no le proporcionó la suficiente resonancia en el mundo científico. El hecho es que tuvo que ser un historiador, Louis Courajod, el encargado de difundir en la década de los ochenta esta interpretación racial y oriental de la arquitectura desde su cátedra de arqueología. El personaje en cuestión, según Francastel plenamente imbuido en una ideología neorromántica de corte católico, merece comentario aparte pues todavía en la actualidad los ecos de su docencia y las polémicas que suscitó siguen en buena medida vivas ${ }^{56}$. Dos de sus discípulos, Lemonnier y Michel, fueron los encargados de publicar de forma póstuma las lecciones que entre 1887 y 1896 Courajod dictó en

BazIN. Germain. Historre de l'histoire de l'art. Paris, Albin Michel, 1986, págs. 296 y ss. La biografia de Courajod fue escrita por André Michel, "Louis Courajod" en Gazette des Beaux- 
el Louvre. Los tres volúmenes de las muy famosas Leçons professées a l'Ecole du Louvre resumen el sentir anticlásico de buena parte de la cultura francesa a lo largo del siglo pues, en efecto, uno de los aspectos más relevantes de su obra debe asociarse a la crítica del clasicismo como «imposición» cultural ajeno a la verdadera vida de los pueblos, como más arriba vimos. En su opinión la propia Historia del Arte con sus cexperiencias de laboratorio" en torno a la formación de los estilos, y por tanto ajenas a la vida profunda de los pueblos, sería un reflejo del academicismo a que se ha querido someter al conjunto de la cultura francesa ${ }^{57}$.

Aunque los textos de Courajod constituyen una "fabulación" menos orgánica que la de Viollet en su interior resuenan multiplicadas las ideas migracionistas del siglo: arios, celtas, germanos, lombardos, todos ellos pertenecientes a un mismo tronco etnológico indoeuropeo incorporaron a la civilización la "lux» de oriente. Además, en vida de Courajod se vive en Francia un momento de especial expansión nacionalista que, como sabemos, hizo particular hincapié en el estudio del problema "celta". Y entre todas las explicaciones parecieron interesarle las de aquellos historiadores o arqueólogos, como es el caso de Bertrand, que explicaron el origen de este pueblo como el de una gran migración procedente de oriente, en este caso de las zonas caucásicas ${ }^{58}$.

La pervivencia y resistencia de los motivos ornamentales celtas a través de los siglos posibilitó su resurrección en los momentos precedentes al período románico, cuando las razas germanas se consolidan como dominadoras de occidente e incorporan a la cultura artística medieval una lejana y ancestral tradición ornamental y constructiva, como es el caso de los lombardos. Para Courajod se trata de la aparición del "alma" o la espiritualidad «septentrional». Al entender la historia del arte como un gran mecanismo etnológico-espiritual, no es extraño que llegue a rechazar la interpretación lógico-constructiva de la arquitectura, que había sido la gran aportación de la arqueología francesa al señalar los mecanismos de con-

\footnotetext{
Arts. Paris, Septembre 1896, págs. 203-217. Sus trabajos fueron ásperamente criticados por el "romanista" Brutails en "Les influences de l'art oriental et les goths dans le Midi de la France" en Anuari de l'institut d'Estudis Catalans. Barcelona, 1907, págs. 29-42. Pierre Francastel en la mencionada $L$ 'histoire de l'art... (págs. 130-131) tuvo palabras muy duras para Courajod al que acusaba de haber suministrado argumentos al imperialismo pangermanista de Strzygowski y, en general, de toda la historiografía alemana. Casi cincuenta años después de la publicación de sus lecciones Pierre Francastel criticaba el reaccionarismo y nacionalismo, al que acompanaban unas buenas dosis de wagnerianismo y primitivismo, de Courajod.

57 Courajod, Louis, Lecons professées a l'Ecole du Louvre (1887-1896). París, Alphonse Picard, 1899-1903, 3 vols, págs. 350, 424 (vol. 1).

58 Bertrand. Alexandre, Archèologie celtique \& gauloise. Paris, Didier et Cie, Libraires-editeurs, 1876, págs. XXIV-XXV
} 
tinuidad entre la tradición clásica, el románico y el gótico. Por ello Courajod exigía ampliar el estudio de los sistemas de abovedamiento al del carácter y la expresión de los edificios medievales ${ }^{59}$.

Bien es cierto que estas propuestas "anti-técnicas" se contradicen con otra sumamente arriesgada en torno al origen de la arquitectura gótica y a la que Viollet no había sido capaz de llegar pues era muy consciente de los procedimientos constructivos. Sin embargo uno de los argumentos centrales de Courajod insiste en- interpretar la obra gótica como trasposición a la piedra de una primigenia arquitectura en madera heredada de la tradición de carpinteros de los denominados pueblos bárbaros. El «pie derecho" como principio generador de la arquitectura gótica que transformó la columna primigenia en el conocido pilar acantonado es un eco de aquella lejana sensibilidad. Los pilares de la impresionante arquitectura normanda de la Abadía de los Hombres de Caen o de la iglesia de Jumieges, ambas con originales cubiertas de madera, son, en opinión de Courajod, recuerdos de aquella práctica. La columna, en síntesis, ha jugado un papel transicional preponderante desde un punto de vista estético y desde ella se impulsó y reveló en forma definitiva la ligereza estructural que se demuestra tanto en el coro de Vezelay como en Notre-Dame de Laon en donde se produce la victoria definitiva de la forma de hacer nórdica sobre la forma latina ${ }^{60}$.

\section{EL FIN DE LA ARQUEOLOGÍA MEDIEVAL}

Las primeras décadas del presente siglo han significado un profundo giro en el sistema de interpretación del arte y arquitectura medievales. Debe constatarse que este cambio de actitud insistirá en el valor de modernidad plástica de este arte frente al filogenismo de la cultura decimonónica. Hecho que puede ser interpretado como el de la drástica muerte de la arqueología medieval y su reconversión en "historia" lo que implica, además, el dominio metodológico de una idea estructural que resuelve provisionalmente la polémica entre "génesis" y "estructura" que afectaba radicalmente a las discusiones entre arqueólogos a lo largo de todo el siglo. Algo de esto ha sido señalado en relación a la interpretación de la arquitectura armenia que realizó Baltrusaitis, pero ya en Courajod está presente el interés por entender el arte medieval como base de una estética moderna que, tras el desgraciado lapsus clásico, comienza a revivir en Francia, siendo su estudio fundamental para "... hacer posible el

s9 Courajod, L., Op. cit, págs. 260-261

6o Courajod Op. cit., pág. 452 (Vol. I). 
retorno al estado del espíritu particular que ha presidido la más maravillosa extensión de nuestro genio francés" ${ }^{61}$.

Tampoco debe olvidarse que, desde finales de siglo, la arquitectura medieval comenzaba a ser analizada desde los criterios estéticos elaborados por las incipientes corrientes funcionalistas. Es así que la edificación de los siglos medios empieza a interpretarse como ejemplo de diferenciación y jerarquización de los elementos cuyas consecuencias son una perfecta claridad volumétrica y formal. Estas tesis, en parte heredadas del racionalismo decimonónico, están presentes en los teóricos de la moderna escuela arqueológica como es el caso de R. de Lasteyrie, Focillon o John Conant, el cual define la complejidad volumétrica de esta arquitectura como de un cpintoresquismo ordenado, basado en una distribución orgánica de elementos funcionales» ${ }^{62}$. Espíritu de modernidad, por tanto, que traspasa su dimensión teórica llegando a influir el propio sentido de la restauración arquitectónica que a partir de estos momentos tendrá como norma reforzar la pretendida diferenciación volumétrica en el proceso de intervención $^{63}$.

El propio Strzygowski, tan preocupado por el problema del génesis, en absoluto fue ajeno al claro dominio de lo estético sobre lo arqueológico. Por ello no es de extrañar la participación del historiador y arqueólogo en el Consejo de Administración del denominado "Círculo de Amigos de la Bauhaus", ambiente en el que se detecta una clara exaltación de los valores poético-arquitectónicos de la remota cultura nórdica como se comprueba en la casa Sommerfeld de Gropius (1920) o en el extraño diseño de casa de madera para la Bauhaus de Weimar realizado por Walter Determann ${ }^{64}$. Interés que el propio Stryzgowski hará explícito años más tarde al definir el arte moderno en su totalidad como el vinculado al expresionismo nórdico; se trató, sin embargo, de una defensa tardía y alejada de la senda estética elegida por el poder político alemán que sólo dos años más tarde realizaría una criba del expresionismo en la muestra nazi sobre el denominado "arte degenerado" ${ }^{65}$.

G Courajod, Op. cit, pág. 289

62 ConANT, J. Arquitectura Carolingia y Rcmánica 800-1200. Madrid, Cátedra, 1982 (1." ed. inglesa de 1954), págs. 40 y ss.

63 ARRECHEA, J., Art. cit

64 Wingler, H., La Bauhaus. Barcelona, Gustavo Gili, 1975 (1. a ed. alemana de 1962), pág 100. El mencionado proyecto de Determann es recogido en Bauhaus 1919-1933. Berlín, Benedikt Taschen, 1991, pág. 42. El interés teórico de este desconcertante proyecto radica en la centralidad absoluta del "hogar" con respecto a la planta del edificio. A este respecto hay que recordar que ya Pictet (vol. 2, págs. 334 y ss.) daba al fuego u uhogar entre los arios un carácter fundacional, tema que recogerá SEMPER, G., en Los Cuatro Elementos de la Arquitectura (1851).

6.5 Strzygowski, J., Civilisations..., pág. 108. 
Dominio de lo estético, ciertamente, pero también dominio de los factores ideológicos, ausencia de rigor positivo e inmensa libertad interpretativa. Será sobre la base de los análisis de Viollet, Courajod y de la escuela bizantinista francesa sobre la que se levante la utopía racial y germanista de Strzygowski que lentamente irá elaborando una compleja cosmología histórica en cuyo final reaparecen, irradiando luz, los «hombres del norte». En efecto, para nuestro arqueólogo tanto el arte oriental como el occidental sólo son pensables remontándonos a unos míticos orígenes que sellaron la distribución de poderes sobre la tierra. Es así que frente al "norte eurásico" y el "sur ecuatorial" se organizó, en el Mediterráneo, un poder teológico y político absolutista desde el cual se acostumbra a considerar la totalidad de la Historia del Arte. "L'art des puissants", como lo denomina Strzygowski, de origen mesopotámico y egipcio, es el reflejo de un sentir "monárquico" que ha buscado consolidarse a través del poder y durabilidad de la piedra. En su opinión es el momento de reivindicar una nordicidad originaria que se remonta a lejanas invasiones europeas del Asia: “Ante nuestros ojos, dirá en 1935, comienzaa surgir un Asia de espíritu claramente nórdico en el que Irán juega un papel intelectual tan decisivo como el que ha jugado Grecia para Europa: ${ }^{66}$.

Nordicidad aria cuya justificación no se encontraba exclusivamente en los teóricos de la escuela vienesa de antropología, sino en las arriesgadas tesis de un gran arqueólogo alemán como lo fue Gustaf Kossinna que desde 1911, y con la publicación de Die Herkfunft der Germanen (El origen de los alemanes), venía sosteniendo la tesis del origen báltico de los pueblos indoeuropeos y la glorificación de una raza suprema biológicamente pura de la cual eran descendientes los actuales alemanes ${ }^{67}$.

La sintesis de Strzygowski, por tanto, se hizo posible por la acumulación de argumentos arqueológicos y raciales tomados a la escuela alemana y su exhaustivo y fino análisis de la arquitectura oriental. En este caso será el norte de Irán, receptáculo de las invasiones arias, la fuente desde donde debe considerarse el origen de todo arte. En efecto, en sus

66 StRzYgowSKI. Civilisations... págs. 80-81. También «Les élements proprement asiatiques dans l'art", en Revue des Arts Asiatiques. París, Tome VI, N. I. 1929, págs. 24-39.

${ }_{67}$ Bosch-Gimpera. El problema indoeuropeo. México, Fondo de Cultura Económico, 1989 (Primera ed. de 1960), págs. 18 y ss. También en Trigger. Op. cit., págs. 157 y ss. En aquellos anos la antropologia e historiografia francesa arremetía duramente contra la teoria racial como método de explicación histórica y especialmente contra el germanismo. Como obra de síntesis ver la obra de PITTARD. E., Les races el l'histoire. París. Albin Michel, 1924. También la obra de Hubert, Henri, Les Germains. París, Albin Michel, 1952 (lecciones en l'Ecole du Louvre de 192526). 
altas mesetas se desarrolló tanto un sentimiento religioso unitario y en expansión hacia Oriente y Occidente como una nueva estética. Su arquitectura está protagonizada por unos magníficos templos, realizados en ladrillo y ya casi borrados, pero que constituyen transposiciones de antiguos prototipos nórdicos elaborados en madera; se trata de la morada indogermana primigenia cuya influencia se puede detectar, paradójicamente, tanto en el templo griego como en la muy posterior arquitectura armenia.

Sentadas las bases de esta especie de filosofía o historia racial del arte, Strzygowski intentó hacer surgir del norte de Irán el desarrollo de un tipo arquitectónico y de una relación de elementos que fundamentaron el arte occidental a partir de la Edad Media. Así frente a la ya tradicional interpretación deudora a Roma, Bizancio o Armenia Strzygowski incide en la aportación de los arcaicos "Templos del Fuego" persas cuya forma cuadrada y estructura centralizada estaba definida por una cúpula sobre trompas sostenida sobre cuatro pilares (fig. 20). En ellos se encuentra el origen de aquella esencial estructura de baldaquino, ya definida por el romanista Quicherat. Forma trascendente, como la raza que la genera, y que veremos reutilizada en Armenia, Bizancio o la Edad Media, aunque también Strzygowski la hará reaparecer en la basílica de San Pedro. Nuestro excéntrico autor no nos hará olvidar que también la iconografía cris. tiana o búdica es heredera de la mazdeísta instaurada fantasiosamente en los ábsides de aquellos templos desaparecidos; pues frente al naturalismo mediterráneo los mazdeístas iranios representan en el fondo de aquellos una atmósfera infinita, los denominados paisajes "Havarenah", en cuyo centro "vagaba la coloreada nube de la aurora»; sofisticación alegórica cuya expansión europea está vinculada, desde la Edad Media a Durero o Friedrich, con la milenaria expansión de las razas indogermanas ${ }^{68}$.

En esta sugerente historia de los orígenes no está presente, sin embargo, una referencia explícita y desarrollada sobre la arquitectura medieval europea. Si Strzygowski pretende demostrarnos el remoto origen que es a la vez oriental, germano y ario de una determinada sensibilidad, no sucede lo mismo con el desarrollo de las formas concretas. El misterio del gótico sigue demasiado lejano a esta estética, tema que el profesor

68 Strzygowski. Joseph, "Le Temple du Feu" en Revue des Arts Asiatiques. Paris, Mars 1927, IV année, N. 1, págs. 1-15. Aunque nunca citado es fundamental la deuda de Strzygowski con el arqueólogo francés Marcel Dieulafoy que años antes publicó el importante $L$ 'Art Antique de la Perse. Achéménides, Parthes, Sassanides... Paris, Librairie Centrale d'Architecture, 1884. 1885,5 vols. 


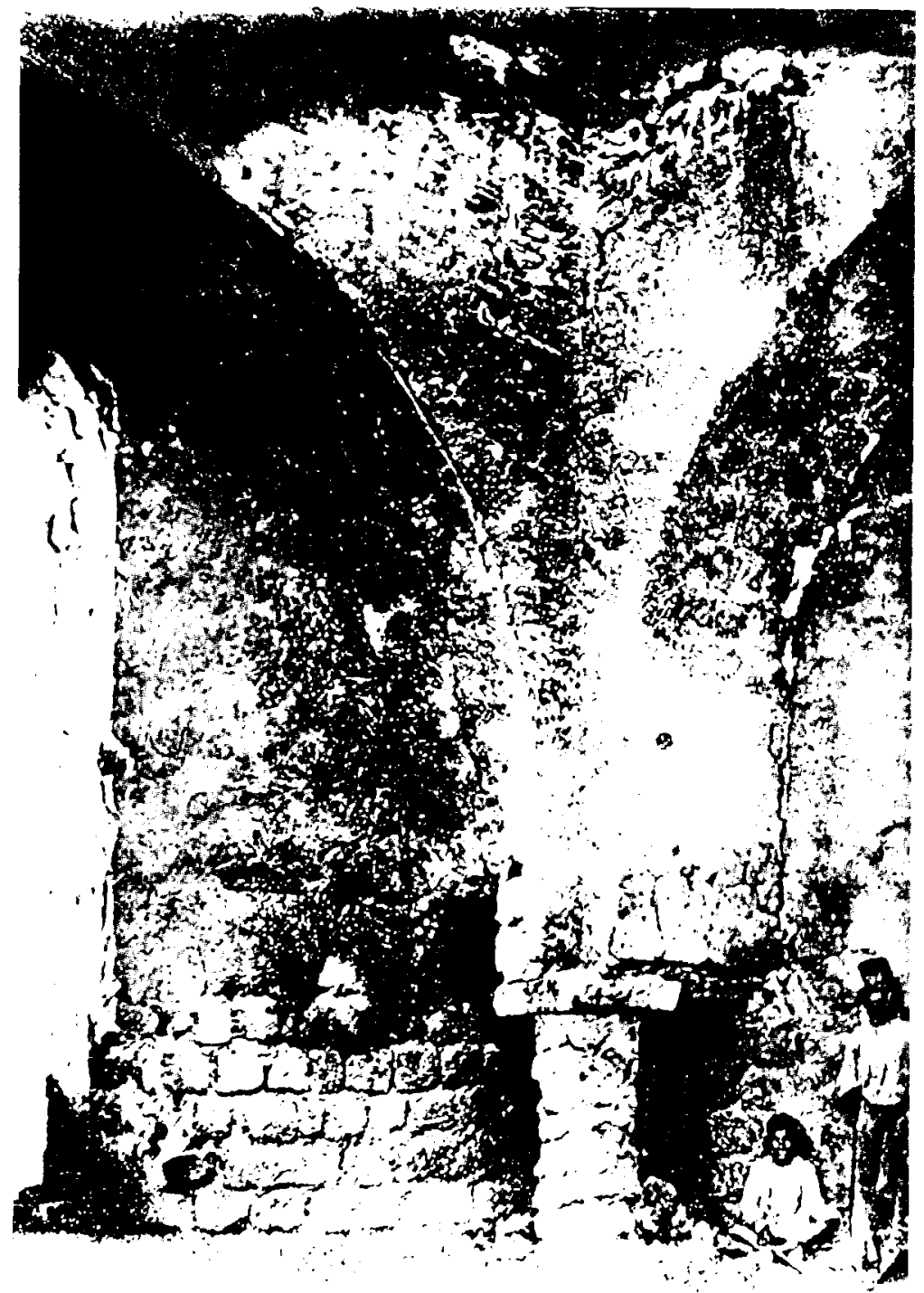

Fig. 20. Dieulafor, Cúpula sobre columnas del palacio persa de Sarvistan, en L'Art Antique de la Perse. Achéménides, Parthes, Sassanides... 1884-1885.

vienés intentará solucionar recurriendo, como Courajod, a lo que constituye la tradición anónima y popular nórdica de la construcción en madera. $Y$ es así como, en su opinión, hay que considerar a las iglesias de los 
pueblos vikingos como precedente constructivo del gótico. De hecho, nos dice Strzygowoski, las características edificatorias originarias de este estilo se relacionan tanto con una tendencia a la numeración y al procedimiento de montaje como con un cierto carácter «orgánico», o de crecimiento, que ya preside la lógica de la arquitectura griega por su similar origen en estructuras de madera ${ }^{69}$.

\section{LA IDEA DE «OCCIDENTE»}

La tesis de Strzygowski eran no sólo descaradamente "pangermanistas" y dispuestas a ver en cualquier fenómeno activo y estéticamente relevante ciertas gotas de "sangre germana", sino que atacaban la raiz misma de la cultura francesa cuyas principales apoyaturas eran, obviamente, el humanismo y el clasicismo. Recordemos a este respecto que una de las mayores operaciones intelectuales de la arquitectura francesa decimonónica fue la de revestir al gótico con los ropajes del "orden», del sentir clásico. La movilización de la cultura francesa no se hizo esperar como vimos en el caso de Maurras. Tampoco los historiadores del arte como Dimier y Màle callaron y ya este último publicó en 1917 un importante texto titulado L'art allemand et l'art francais du Moyen Age en el que atacaba la infertilidad artística de los pueblos "bárbaros".

Cuando en 1935 se desató en el Boletín de la Sociedad de Naciones la polémica pública de la que venimos hablando, y que resumía casi un siglo de controversias lingüisticas, etnológicas y estéticas, fue Focillon el encargado de devolver la confianza al clasicismo. La contestación a Strzygowski en Civilisations... es sofisticadamente matizada. Obviamente el escritor francés era muy consciente de las múltiples influencias formales que recorren la historia. Su interés por Armenia, İlanda o España así lo confirman.. Oriente se inmiscuye y roza la cultura de occidente, pero lo que Focillon se niega a tener presente como esencia de sus interpretaciones es la tensión del "origen" que dominaba la historiografía; su sentido estructural de la "forma" como proceso de compleja constitución, casi geológico, se lo impedía. Para él, como para Baltrusaitis, tienen más interés el lento deambular de los signos y los correspondientes procesos de mutación o metamorfosis que el establecimiento de una mítica genealogía $^{70}$ (fig. 21).

69 Strzrgowski. Joseph, "Les origines de l'Art Gothique". en L'Amour de l'Art. París, 1932. Mars. N. 3, págs. 83-94

70 En sus ya citados Etudes sur l'art médiéval en Geórgie et en Arménı Baltrusaitis plantea el problema de las influencias orientales en la cultura occidental, teniendo en cuenta que cla identidad de temas no establece la identidad estilitica" y que la homologia formalista representa valorar en el arte "en lo que hay de más neutro, menos activo y menos personal" (pág. 65) 

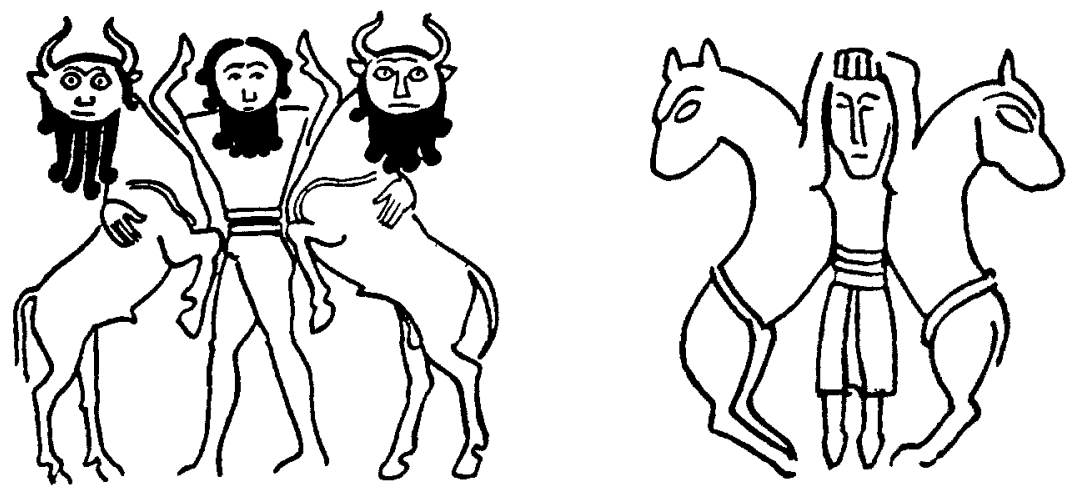

Fig. 21. Balirusaitis. Metamortosis de las formas: 1 Our. tumba del rey. 2. Capitel románico de Estany.

La "vida de las formas" no se debe reducir a su génesis sino a su constante resurrección en el espíritu. Es allí donde en cada momento de la historia han tomado sentido, se han rehecho con significados siempre antiguos y nuevos.

No es de extrañar, por tanto, el rechazo que Focillon sintiera hacia aquel especto de la obra de Strzygowski caracterizada por el determinismo étnico-estético que asignaba a los pueblos germanos el principio y fin de todo arte. En la Vie des formes ya realizaba una dura crítica a estos conceptos y denunciaba la apropiación "nórdica" que se habia hecho de la decoración geométrica y de entrelazos que en su opinón constituyen la base de un patrimonio colectivo heredado de la humanidad primiti$\mathrm{va}^{71}$. Por ello su contestación epistolar insiste en negar, en primer lugar, la existencia de cualquier raza no marcada por la mezcla y, a continuación, criticar la pretendida superioridad espiritual y artística de los pueblos germanos en base al airaso que constituye la permanencia de la civilización de la madera, precisamente lo que para Strzygowski constituye su gran virtud.

Focillon insistió, frente al "pangermanismo" radical, en la defensa de una latinidad amenazada, de un mundo mediterráneo que justamente estableció los principios de orden, medida y ritmo contra los pueblos bárbaros. Latinidad, que en sus momentos de auge, el Imperio y la paz romana, configuró no sólo unos principios morales sino una estructura inte- 


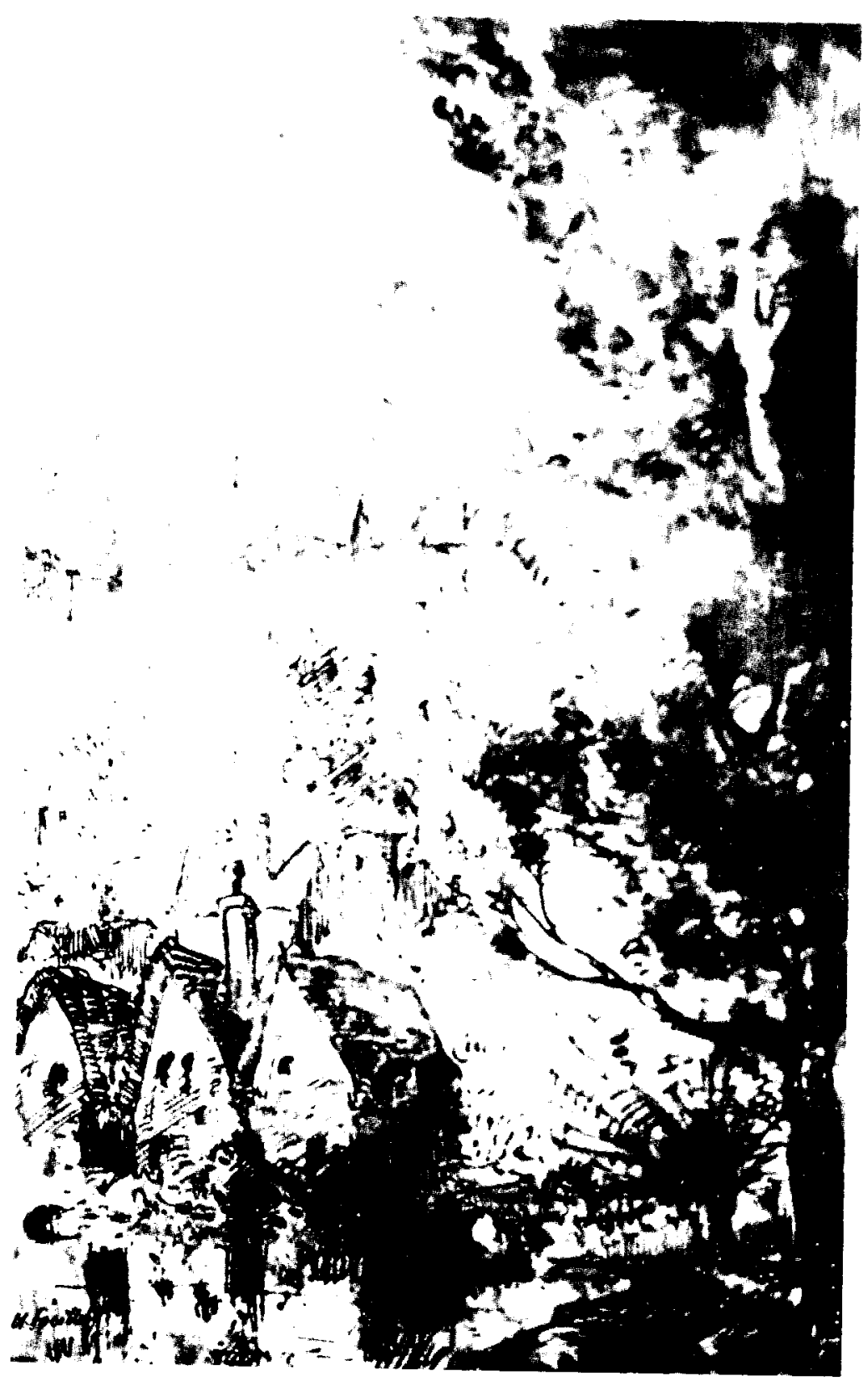

Fig. 22. Focillon. Chartres. 
gradora que superó la particularidad de los pueblos a través de la técnica, las leyes y la lengua. Por último, y según Focillon, la latinidad es todavía algo más que todo lo anterior: es un mito; leyenda necesaria construida en la imaginación de los pueblos y cuyo recuerdo y ejemplo emerge periódicamente desde la Edad Media ${ }^{72}$.

Aquella tradición latina, acrecentada con una multiplicidad compleja de influencias tanto nórdicas como mediterráneas, finalizó por reelaborar una idea sintética y ecléctica del arte y la cultura. Idea clave, denominada "Occidente", cuyo poso original se encuentra en primer lugar en una nueva mentalidad racionalista, enciclopédica y no particularista, e igualmente en la lenta evolución urbana de la Edad Media, en el nacimiento de la nueva burguesía y en la construcción del sueño de las grandes catedrales (fig. 22). Como fenómeno histórico la construcción de Occidente, determinada por la aparición de la ciudad burguesa, señalará Focillon, no puede pensar en su arquitectura como originaria de los bosques. De hecho, ios problemas de estática, técnicos o plásticos presentes en la arquitectura gótica conciernen directamente a la piedra pues tanto la bóveda de aristas como la de crucería se remiten a viejas tradiciones mediterráneas, desde Armenia hasta el Califato español ${ }^{73}$.

El papel que la idea de Occidente juega en Focillon tiene, por tanto, una explicación que parte de un contexto francamente turbulento. Heredados problemas ideológicos e historiográficos convierten esta idea en absolutamente imprescindible para el sostén de la cultura artística francesa si no quiere perder su carácter de centralidad, pues, para Focillon, Francia es Occidente. Pero, sin duda, y a pesar de su tendenciosidad, sigue resultando atractivo y verdadero el viejo argumento del autor francés sobre el origen primordial de la colurnna; que esta «... haya tenido, entre los Bárbaros, un modelo en madera, no se puede negar; sin embargo, no es esto lo importante de admirar, sino el sentir matemático que mide y distribuye las partes" ${ }^{74}$.

Civilisations... págs. 137-145.

Op. cit., págs. $156 \cdot 158$.

Op. cit., pág. 138. 
